\title{
Computer Integrated Manufacturing of Polyurethane Foams Steered by Measured and Calculated Data in Comparison
}

\author{
Heinrich Horacek ${ }^{*}$
}

Free Consultance, A-4048 Puchenau, Am Wieserain 1, Austria

\begin{abstract}
Polyurethane foams were manufactured under continuous measurements of isocyanate content, temperature, expansion and viscosity. Parallel model calculations were executed based on the driving force of $50 \mathrm{~kJ} / \mathrm{mole}$ heat of reaction of the energy rich isocyanate group and on thermodynamic balances of weight and heat of formation as well as on a kinetic model using a first order reaction for the isocyanate consumption and a relation for the viscosity dependent on conversion and on a viscosity constant. The agreement between continuous measured and calculated data was satisfying. The parameters isocyanate content, temperature, expansion and viscosity controlled and steered the variables of the production plant, like dosage of components, temperature and conveyer speed. The kinetic model was also valid for polyurethane foams with additives, which did not react with components of foam, like flame retardants or pigments. The thermodynamic balances of weight and heat predicted residues and consumed heats by degradation under fire, which correlated with those measured by TGA and DSC. The target was to establish computer integrated manufacturing without continuous measurements but by mere model calculation. This was possible with the knowledge of the first order velocity constant and the viscosity constant.
\end{abstract}

Keywords: Thermodynamic, Kinetic, foaming model, flame retardants.

\section{INTRODUCTION}

World wide 15 Mio metric tons polyurethane have been produces in 2014. Half of them are foams: rigid foams with compressive strength about $0.100 \mathrm{MPa}$ for insulation in buildings and soft foams with compressive strength of $0.003 \mathrm{MPa}$ for mattresses for furniture. Though the commercial importance is high, still improvable aspects are the safe and economic production of efficient flame retarded polyurethane foams by computer integrated manufacture [1-13].

Computer integrated manufacturing CIM is the integration of total manufacturing enterprise by using integrated systems and data communication coupled with new managerial philosophies that improve organizational and personnel efficiency. In the 1980's the CIM wheel has been invented by CASA/SME (Computer and Automated System Association of the Society of Manufacturing Engineers of the USA), which is steered by the integrated system architecture with common data and information resource management and communication. The CIM wheel is further developed to the Manufacturing Enterprise Wheel, where in the centre is no longer the integrated system architecture but the customer.

The software to manage a continuous production of flexible polyurethane foams by slabstock technology is available [14-19]. Continuous measurements are

${ }^{*}$ Address correspondence to this author at the Free Consultance, A-4048 Puchenau, Am Wieserain 1, Austria; Tel: 0043-732-73-70-83;

E-mail: heinrich.horacek@aon.at described concerning the temperature with contactless pyrometer determining the IR radiation emitted from the foam and those of the expansion of the foam by ultra sound distance sensors in order to steer the controlled variables as conveyer speed, composition of the materials, temperature of materials, temperature of facing layers fed to the process and temperature of pouring plate. A new aspect is introduced by continuously measuring isocyanate consumption, viscosity and by using a foaming model in addition.

Therefore soft foam formulations with the flame retardants melamine [20] and aluminium trihydrate [21] and rigid foam formulations in the presence of ammonium polyphosphate [22] or polyisocyanurate foams [23-25] in combination with tris butoxyethylphosphate are investigated. During the foaming process the isocyanate concentration is recognized by IR spectroscopy, the temperature by contactless IR thermo sensors, the expansion height by ultrasound distance sensors and the viscosity by an oscillating viscometer. The produced foams are characterized by their density, tensile strength, compressive strength and burning behaviour [26]. The decomposition of the foams is followed by DSC and TGA measurements.

Furthermore balances of weight and heats of formation are established, which allow to follow the path of synthesis, which is driven by the energy rich isocyanate bond with $50 \mathrm{~kJ} / \mathrm{mole}$, which is deduced from the balances of heat. $75 \mathrm{~kJ} / \mathrm{mole}$ is published for the reaction between methanol and methylisocyanate [27]. 
For the reaction $-\mathrm{N}=\mathrm{C}=\mathrm{O}+\mathrm{O}-\mathrm{H}=-\mathrm{NH}-\mathrm{COO}$ - the $\mathrm{N}=\mathrm{C}$ bond $(615 \mathrm{~kJ} / \mathrm{mole})$ and $\mathrm{O}-\mathrm{H}$ bond $(463 \mathrm{~kJ} / \mathrm{mole})$ have to be broken and the bonds $\mathrm{N}-\mathrm{H}(305 \mathrm{~kJ} / \mathrm{mole}), \mathrm{C}$ $\mathrm{N}(391 \mathrm{~kJ} / \mathrm{mole})$ and $\mathrm{C}-\mathrm{O}(358 \mathrm{~kJ} / \mathrm{mole})$ will be made. By difference a reaction heat of $24 \mathrm{~kJ} / \mathrm{mole}$ is gained [28].

Synthesis of $n$ moles of reactants with equivalent weight EWn (g/equivalent) and heat of formation $\mathrm{Hfn}$ ( $\mathrm{JJ} /$ equivalent weight) react under heat of reaction $\mathrm{H}$ to polyurethane:

$\mathrm{n}{ }^{*} \mathrm{EWn}$ reactants $=\mathrm{EW}$ polyurethane

$\mathrm{n}^{*} \mathrm{Hfn}$ reactants $+\mathrm{H}=\mathrm{Hf}$ polyurethane

When the amounts of flame retardants are sufficient, then burning is prevented and only decomposition takes place, which also can be described by the balances of weight and heat.

Polyurethanes decompose under heat development $\mathrm{H}(\mathrm{kJ} / \mathrm{mole})$ to gaseous or solid decomposition compounds. The residues $\mathrm{R} \%$ and heats of decomposition $\mathrm{h}(\mathrm{kJ} / \mathrm{g})$ are calculated and compared with those measured by DSC and TGA experimentally:

EW polyurethane $=n * E W n$ decomposition products

$\mathrm{Hf}$ polyurethane $+\mathrm{H}=\mathrm{n}^{*} \mathrm{Hfn}$ decomposition products
Also a kinetic foaming model is developed. The isocyanate conversion $U$ follows a first order velocity reaction with $\mathrm{C}_{01}$ the isocyanate initial concentration and $\mathrm{k}_{1}$ the velocity constant:

$\mathrm{U}=1-1 /\left(\mathrm{k}_{1} * \mathrm{c}_{01} * \mathrm{t}-1\right)$

equ.1

In the formulations the observed heat of reaction $\mathrm{H}$ depends on the initial concentration $\mathrm{C}_{01}$ of isocyanate groups with $50 \mathrm{~kJ} / \mathrm{mole}$ bond energy and on the conversion $\mathrm{U}$ :

$\mathrm{H}=50^{*} \mathrm{C}_{01}{ }^{*} \mathrm{U} / 100$ ( $\mathrm{kJ} /$ equivalent weight). When $\mathrm{H}$ is divided by the equivalent weight of $\mathrm{NCO}=42 \mathrm{~g} / \mathrm{mole}$, then $\mathrm{h}=11.9^{*} \mathrm{C}_{01}{ }^{*} \mathrm{U}(\mathrm{kJ} / \mathrm{kg})$ is obtained.

$\mathrm{h}=11.9 * \mathrm{c}_{01} * \mathrm{U}$

equ. 2

Foaming can take place by chemical blowing in the water reaction, where $\mathrm{c}_{02}$ is the initial water concentration of the formulation.

Foaming can take place by physical blowing with an auxiliary blowing agent as pentane with the initial concentration $\mathrm{C}_{03}$.

The increase in viscosity starts with the initial viscosity vo and follows equation 3 :

Table 1: Chemicals Used

\begin{tabular}{|c|c|c|c|}
\hline Brand name & Company & Formula & Abbreviation \\
\hline Desmophen $7652 Y$ & Bayer & $\left(\mathrm{C}_{32} \mathrm{H}_{6} \mathrm{O}\right)_{32}$ & \\
\hline Diethanolamine & BASF & $\mathrm{C}_{4} \mathrm{H}_{11} \mathrm{NO}_{2}$ & \\
\hline Dabco 33 LV & Bayer & & \\
\hline Dibutyltindilaurate & Bayer & & \\
\hline Stabilisator AC 3367 & Goldschmidt & & \\
\hline Tolylene diisocyanate & Bayer & $\mathrm{C}_{9} \mathrm{H}_{6} \mathrm{~N}_{2} \mathrm{O}_{2}$ & \\
\hline Caradole 520 & Shell & $\left(\mathrm{C}_{3} \mathrm{H}_{6} \mathrm{O}\right)_{2}$ & \\
\hline n-Pentane & Haltermann & $\mathrm{C}_{5} \mathrm{H}_{12}$ & \\
\hline Exolite 420 & Lanxess & $\left(\mathrm{NH}_{4} \mathrm{PO}_{3}\right)_{\mathrm{n}}$ & APP \\
\hline Caradate 30 & Shell & $\mathrm{C}_{16} \mathrm{H}_{12} \mathrm{~N}_{2} \mathrm{O}_{2}$ & \\
\hline Castor oil & Bayer & $\mathrm{C}_{18} \mathrm{H}_{34} \mathrm{O}_{3}$ & \\
\hline Lupranol 3602 & BASF & $\left(\mathrm{C}_{3} \mathrm{H}_{6} \mathrm{O}\right)_{3}$ & \\
\hline Glycerol & Bärlocher & $\mathrm{C}_{3} \mathrm{H}_{8} \mathrm{O}_{3}$ & \\
\hline 2Polycat 41 & Abbott & Dimethylaminopropyl hydrotriazin & \\
\hline K-formiate & BASF & & \\
\hline Melamine & BASF & $\mathrm{C}_{3} \mathrm{H}_{6} \mathrm{~N}_{6}$ & M \\
\hline Tributoxyethylphosphate & Clariant & $\mathrm{C}_{18} \mathrm{H}_{39} \mathrm{O}_{7} \mathrm{P}$ & TBEP \\
\hline Martinal OL107 LEO & Martinswerke & $\mathrm{Al}(\mathrm{OH})_{3}$ & ATH \\
\hline
\end{tabular}


$\mathrm{v}=\mathrm{v}_{0} * \mathrm{k}_{2}{ }^{\mathrm{U}}$

equ. 3

$k_{2}$ is a constant parameter for each formulation.

\section{EXPERIMENTAL}

\section{Chemicals}

All chemicals used in the formulations for polyurethane foams were collected in Table 1.

\section{Equipment and Materials}

Combustion Modified High resilient foam CMHR, rigid foam PU and polyisocyanurate foam PIR were produced. During foaming over the first 10 minutes the isocyanate concentration was determined by Fourier transmission infrared FTIR spectroscopy by diminished reflection ATR of the foam using the ratio of intensity of the $\mathrm{NCO}$ band at $2270 \mathrm{~cm}^{-1}$ and the $\mathrm{CH}$ band at 3040 $\mathrm{cm}^{-1}$. A FTIR Spectrometer Digilab 15B/D and a liquid light guide from Lumatec were used. The continuous IR measurements were controlled and gauged by titration of the NCO content in samples taken in time intervals. The temperature of the foam was measured by IR radiation measurement, which were performed with contactless IR thermo sensors OS 35 (Omega) and the viscosity was determined by an oscillating viscometer. The oscillating viscometer consisted of a torsion wire with a turning body, which dipped into the foam. A generator produced the oscillation, which was enhanced by operating amplifier. A stimulating coil induced oscillation to the permanent magnet. The increasing viscosity of the foam weakened and retarded the primary oscillation and produced a secondary oscillation. The secondary oscillation was transmitted over reception coils to the measuring coil and transmitted to the carrier frequency bridge. A frequency analyzer visualized the secondary oscillation.

The expansion was determined by the ultra sound distance sensor nano 24/CE from microsonic. The manufactured foams were characterized by the tensile strength the compressive strength measured on Autograph AG-X Series (Shimadzu).

The combustion behaviour was investigated by Cone Calorimeter Fire Testing Technology CFTT conformable to ASTM E 1354-1992 and by LOI measurements. Soft foams were tested under conditions described in the British Standard 5952 Part 2 Crib 5. The combustion behaviour of rigid foams was tested according DIN 4102 and the Single Burning Item Test. Their weight losses were determined as described in ASTM D3014.

Furthermore thermogravimetric analysis TGA as well as differential scanning calorimetry DSC were performed on a Mettler Toledo TMA/SDTA 840 with TGA/SDTA 851 Modul. The intumescent ingredients were characterized by thermal gravimetric analysis (TGA) on a Mettler Toledo TMA/SDTA with TGA/SDTA 851 Modul. The samples were placed in aluminium oxide crucibles of $900 \mu \mathrm{l}$ volume (ME 511119, 960) with $12 \mathrm{~mm}$ diameter covered by punctured lids. The TGA measurements took place under air or nitrogen with $80 \mathrm{ml} / \mathrm{min}$ and heating rates of $5-20 \mathrm{~K} / \mathrm{min}$. The TMA measurements were performed in aluminium oxide crucibles with $7 \mathrm{~mm}$ diameter and $4.6 \mathrm{~mm}$ height covered by $6 \mathrm{~mm}$ diameter lids in air or under nitrogen at heating rates of 5 to $20 \mathrm{~K} / \mathrm{min}$.

The heats of combustion hcomb were measured in a calorimeter according to DIN 51900 Teil 2 (1977) Heizwertbestimmung.

$\mathrm{C}$ (ombustion) $\mathrm{M}$ (odified) $\mathrm{H}$ (igh) $\mathrm{R}$ (esilient) foam was manufactured in large scale on a Maxfoam plant from Cannon shown in Figure 1 as scheme. The plant was equipped with a FTIR apparatus together with a light guide combined with FTIR applying the diminished total reflection technology for the determination of the isocyanate content 6 , with IR thermo sensors OS 35 (Omega) for temperature measurements 7 , with an oscillating viscometer for the continuous recognition of viscosity 8 , with ultrasonic sensors Nano-24/CD (microsonic) for the continuous measurement of expansion 9.

The production plant consisted of a decentralized hardware concept. A central computer communicated with two multiplexers, one, which concentrated the data of the micro steered plant, and another, which concentrated the data for apparatus, which determined controlled variables of the plant.

The measured data were transmitted to Multiplexer for concentration of the data. A central computer was enabled to compare the measured data with the required data and to inter- or extrapolate data with the help of the foaming model. The central computer gave order to the second Multiplexer, which governed the plant.

By a master system a central computer 1 controlled the communication and integrated functions of the plant 


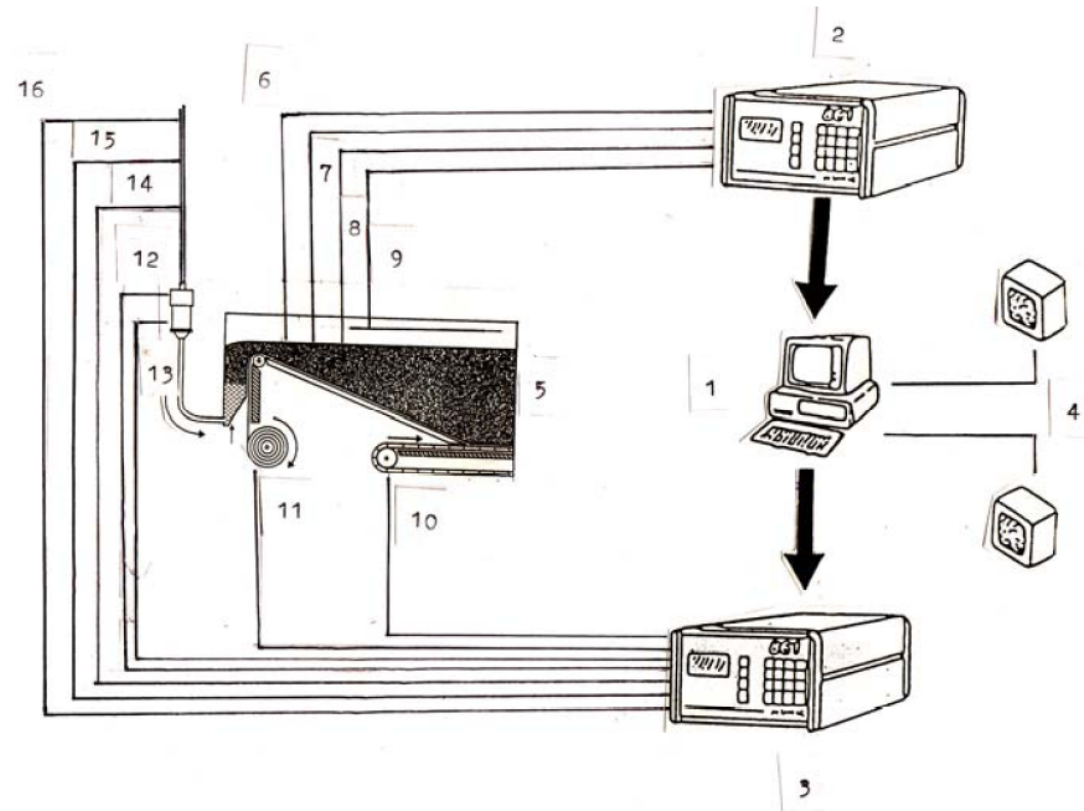

Figure 1: CIM schemata for the Maxfoam plant: 1 central computer, 2 multiplexer for input data, 3 multiplexer for output data, 4 video screens, 5 foam, 6 IR sensor for NCO concentration, 7 temperature sensor, 8 viscosity sensor, 9 expansion sensor, 10 speed regulator for the conveyer, 11 temperature control of facing layers, 12 speed regulator in the mixing head, 13 pressure regulator in the mixing head, temperature regulator in the mixing head, 14 temperature control of the components, 15 control of component composition and 16 the dosage of dispersed gases.

incorporating each individual production area. The central computer communicated with the production line via area specific personal computers equipped with task oriented polyurethane specific software.

The multiplexer 2 concentrated the input data and transmitted them to the central computer 1 . The central computer checked the data inter- and extrapolated the data supported by the foaming model and gave order to multiplexer 3 , which concentrated the data for relay transmitters steering the plant. The whole plant was governed by microprocessors: the conveyer speed 10 , the temperature of facing layers fed to the foaming process 11 , the revolution in the mixing head 12 , the pressure in the mixing head 13 , the temperature of the components 14 , the composition of the components 15 and the dosage of dispersed gases 16 were controlled and steered.

\section{FORMULATIONS}

\section{Combustion Modified High Resilient Foam}

In Table 2 the ingredients were summarized for the manufacture of flexible foam for mattresses. The providing companies, the parts, the formulas, the equivalent weights $\mathrm{EW}$ and the equivalents $\mathrm{E}$ were pointed out. The index I corresponded to the equivalents isocyanate divided by the sum of equivalents of isocyanate consuming components.
The measured data for the isocyanate content $c_{1}$, the conversion of isocyanate $U$, the viscosity $v$, the temperature $T$ and the expansion $b$ for the CMHR foam during the first 10 minutes were recorded in Table 3.

Over the period of 10 minutes the $\mathrm{NCO}$ content $\mathrm{c}_{1}$, decreased from 12 to $0.9 \%$, the conversion $U$ reached nearly 1 , the viscosity $v$ started with $0.5 \mathrm{~Pa}^{*} \mathrm{~s}$ and reached $1.8^{*} 10^{2} \mathrm{~Pa}^{*} \mathrm{~s}$, the temperature $\mathrm{T}$ increased from room temperature to $123^{\circ} \mathrm{C}$ and the expansion $\mathrm{b}$ ended with 36. The expression $b$ was defined as density of the unexpanded foam $1000 \mathrm{~kg} / \mathrm{m}^{3}$ divided by the density of the expanded foam minus 1 .

$$
\mathrm{b}=\left(1000 / \mathrm{d}_{\mathrm{f}}\right)-1
$$

equ. 4

In this case the density of the foam df amounted $27 \mathrm{~kg} / \mathrm{m}^{3}$.

The conversion $U$ was defined as $\left(c_{01}-c_{1}\right) / c_{01}$ with co1 as the initial NCO concentration

As the flame retardants did not react with the ingredients, the FR's could be treated separately.

Vapour pressure measurements of melamine opened the possibility to determine the heat of sublimation of melamine $0.97 \mathrm{~kJ} / \mathrm{g}$ using the equation of Clausius Clapeyron. 
Table 2: Formulation of High Resilient Foam HR- and CMHR-Foam

\begin{tabular}{|c|c|c|c|c|c|c|}
\hline Ingredients & Company & parts & Formula & EW & $E$ & $\%$ \\
\hline Desmophen 7652Y & Bayer & 100 & $\left(\mathrm{C}_{3} \mathrm{H}_{6} \mathrm{O}\right)_{32}$ & 1856 & 0.054 & \\
\hline Diethanolamine & BASF & 2 & $0.33^{*} \mathrm{C}_{4} \mathrm{H}_{11} \mathrm{NO}_{2}$ & 35 & 0.057 & \\
\hline Dabco 33LV & Bayer & 0.1 & & & & \\
\hline DBTDL & Bayer & 0.19 & & & & \\
\hline Stab. AC 3367 & Goldschmidt & 0.259 & & & & \\
\hline TDI $8048 \%$ NCO & Bayer & 50.7 & $0.5^{*} \mathrm{C}_{9} \mathrm{H}_{6} \mathrm{~N}_{2} \mathrm{O}_{2}$ & 87 & $0.583 c_{01}$ & 12 \\
\hline Melamine & Sum & 157.3 & & & $\mathrm{cM}$ & 22,3 \\
\hline
\end{tabular}

Index $=0.583 / 0.555=1.05$

Three samples were manufactured:

1. HR-foam without flame retardant.

2. CMHR-foam with $22.3 \%$ melamine.

3. CMR-foam with $43.0 \%$ aluminium trihydrate.

Table 3: Experimental Data for CMHR-Foam with $22.3 \%$ Melamine

\begin{tabular}{|c|c|c|c|c|c|}
\hline time $\min$ & $c_{1} w \%$ & U & Igv $\mathrm{Pa}^{*} \mathrm{~s}$ & $\mathrm{~T}^{\circ} \mathrm{C}$ & b \\
\hline 0 & 12 & 0 & -0.3 & 25 & 0 \\
\hline 2 & 5 & 0.58 & 1.6 & 85 & 35 \\
\hline 3 & 3.5 & 0.71 & 1.8 & 94 & 36 \\
\hline 5 & 2.5 & 0.79 & 2.05 & 104 & 36 \\
\hline 6 & 2 & 0.83 & 2.1 & 109 & 36 \\
\hline 7 & 1.5 & 0.88 & 2.15 & 113 & 36 \\
\hline 8 & 1.3 & 0.89 & 2.2 & 117 & 36 \\
\hline
\end{tabular}

The balances of weight and heat determined $1 \mathrm{~kJ} / \mathrm{g}$ heat of sublimation.

By sublimation melamine evolved 1 mole gas or $419 \mathrm{ml} / \mathrm{g}$ gas:

$\mathrm{V}_{\text {gas }}=22400 *(1+370 / 273) / 126=419 \mathrm{ml} / \mathrm{g} \quad$ equ. 5

Melamine burned and produced 9 mole or $3768 \mathrm{ml} / \mathrm{g}$ gas under $-15,6 \mathrm{~kJ} / \mathrm{g}$ heat evolution.

$\mathrm{V}_{\text {gas }}=9 * 22400 *(1+370 / 273) / 126=3768 \mathrm{ml} / \mathrm{g}$ equ. 6
The TGA measurements of HR without melamine and CMHR with $22.3 \%$ melamine were performed under air and nitrogen at a heating rate of $10 \mathrm{~K} / \mathrm{min}$ and visualized in Figure 2. After differentiation the HR foam under nitrogen showed two peaks, one with $40 \%$ residue at $280^{\circ} \mathrm{C}$ and the other with $10 \%$ at $380^{\circ} \mathrm{C}$. In air decomposition was enhanced but led to a higher amount of oxidized products resulting in more residues at $500^{\circ} \mathrm{C}$.

The flame retardant $\mathrm{Al}(\mathrm{OH})_{3}$ was tested as possible alternative to melamine. 


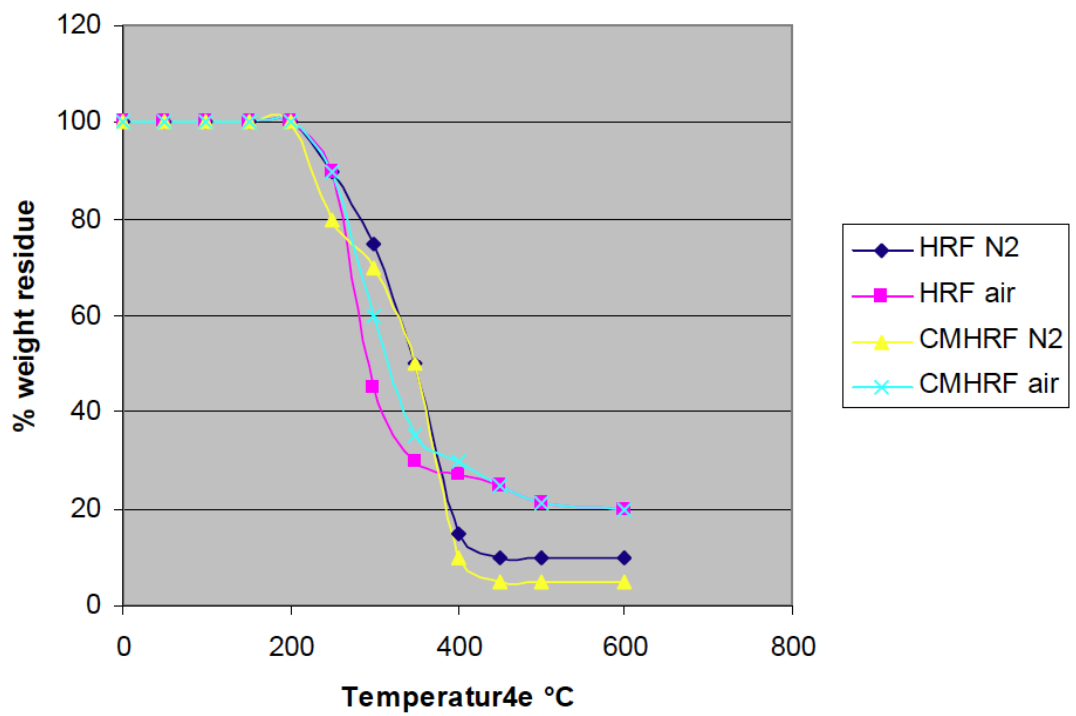

Figure 2: TGA in air and under nitrogen: HRF-Foam and CMHR-Foam, heating rate 10K/min. After differentiation peaks of decomposition occurred at $280^{\circ} \mathrm{C} \mathrm{R}=60 \%$ and at $380^{\circ} \mathrm{C} \mathrm{R}=10 \%$ for $\mathrm{HRF}$ in nitrogen and at $250^{\circ} \mathrm{C} \mathrm{R}=50 \%$ and $380^{\circ} \mathrm{C} \mathrm{R}=25 \%$ in air. CMHR exerted peaks at $250^{\circ} \mathrm{C} \mathrm{R}=80 \%, 300^{\circ} \mathrm{C} \mathrm{R}=50 \%$ and $380^{\circ} \mathrm{C} \mathrm{R}=5 \%$ under nitrogen at $250^{\circ} \mathrm{C} \mathrm{R}=60 \%$ and $380^{\circ} \mathrm{C} \mathrm{R}=$ $25 \%$ in air.

At $300^{\circ} \mathrm{C}$ aluminium trihydrate split off $452 \mathrm{ml} / \mathrm{g}$ water under $1,18 \mathrm{~kJ} / \mathrm{g}$ heat uptake measured by DSC.

$\mathrm{V}_{\text {gas }}=1.5 * 22400 *(1+300 / 273) / 156-452 \mathrm{ml} / \mathrm{g}$ equ. 7

In the limiting oxygen test (LOI test) melamine was twice more active than $\mathrm{Al}(\mathrm{OH})_{3}$.

$$
\mathrm{LOI}=19+0.29 * \mathrm{~W} \% \text { melamine } \quad \text { equ. } 8
$$$$
\mathrm{LOI}=19+0.15^{*} \mathrm{w} \% \mathrm{Al}(\mathrm{OH})_{3} \quad \text { equ. } 9
$$

When $22.3 \mathrm{w} \%$ melamine were added, a LOI value of $25.5 \%$ was reached, the same LOI value was achieved by the addition of $43 \% \mathrm{Al}(\mathrm{OH})_{3}$.

The foams comprising $22.3 \%$ melamine and $43 \%$ ATH fulfilled the demands of the British Standard test BS 5852 Part 2 Crib 5: flame extinguished after 10 minutes, no smoke after 60 seconds and weight loss less than $6 \%$. As a consequence of high filling the flexible foam with $43 \%$ aluminium trihydrate was no longer high resilient. The CMHR foam based on melamine was also investigated by Cone calorimeter at a heat flux of $50 \mathrm{~kW} / \mathrm{m}^{2}$. The rate of heat release RHR was as much as $1200 \mathrm{~kW} / \mathrm{m}^{2}$ for the HR foam and was reduced to $600 \mathrm{~kW} / \mathrm{m}^{2}$ for the CMHR foam.

\section{Rigid PU Foam}

Rigid PU foams applied in the building industry as insulating material were submitted various fire tests like
DIN 4102 or the Single Burning Item Test with the classifications $\mathrm{B} 1$ and $\mathrm{B} 2$ or $\mathrm{A}, \mathrm{B}$ and $\mathrm{C}$.

In Table 4 the formulation of the rigid foam without flame retardant was summarized.

Two types of rigid foam were manufactured one without flame retardant and one with the flame retardant ammonium polyphosphate. APP burned under $-3.5 \mathrm{~kJ} / \mathrm{g}$ heat development.

In the DSC investigation ammonium polyphosphate exerted two heat sinks one at $350^{\circ} \mathrm{C}$ with $0.56 \mathrm{~kJ} / \mathrm{g}$ and one at $700^{\circ} \mathrm{C}$ with $1.9 \mathrm{~kJ} / \mathrm{g}$. Over all 1.5 moles of gas were split off.

$\mathrm{V}_{\text {gas }}=1.5 * 22400 *(1+320 / 273) / 97=752 \mathrm{ml} / \mathrm{g}$ equ. 10

In the run of a TGA measurement rigid foams $\mathrm{PU}$ without flame retardant PU and with $12.4 \%$ APP FR-PU were heated at a rate of $10 \mathrm{~K} / \mathrm{min}$ in air.

In the Cone calorimeter with a heat flux of $5 \mathrm{~kW} / \mathrm{m}^{2}$ the rate of heat release was reduced from $120 \mathrm{~kW} / \mathrm{m}^{2}$ for the PU foam to $40 \mathrm{~kW} / \mathrm{m}^{2}$ for the PU-FR foam with $12.4 \%$ APP.

The weight loss of the PU-FR was determined according to ASTM D-3014. With $12.4 \%$ APP a weight loss of $13.3 \%$ was observed.

Weight loss $\%=53-3.8^{*} \mathrm{~W} \% \mathrm{APP}$ equ. 11 
Table 4: Formulation of rigid foam PU and FR-PU

\begin{tabular}{|c|c|c|c|c|c|c|}
\hline Ingredients & Company & parts & Formula & EW & E & $\%$ \\
\hline Caradol 520 & Shell & 100 & $\left(\mathrm{C}_{3} \mathrm{H}_{6} \mathrm{O}\right)_{1.86}$ & 108 & 0.925 & \\
\hline Dimethylethanolamine & BASF & 3 & $\mathrm{C}_{4} \mathrm{H}_{11} \mathrm{NO}_{2}$ & 35 & 0.0864 & \\
\hline DBTDL & Bayer & 0.06 & & & & \\
\hline Water & & 2 & & 9 & $0.222 c_{02}$ & 0,62 \\
\hline DC 193 & Dow Corning & 0.1 & & & & \\
\hline Pentane & Haltermann & 10.9 & & & $\mathrm{C}_{03}$ & 3,4 \\
\hline Caradate $30(\mathrm{NCO}=31 \%)$ & Shell & 166 & $\mathrm{C}_{8} \mathrm{H}_{6} \mathrm{NO}$ & 132 & $1.258 \mathrm{C}_{01}$ & 16 \\
\hline \multirow{3}{*}{ APP } & Sum & 282.06 & & & \multirow{3}{*}{ cAPP } & \multirow{3}{*}{12.4} \\
\hline & Clariant & 39.90 & & & & \\
\hline & Sum & 321.96 & & & & \\
\hline
\end{tabular}

$I=1.258 / 1.233=1.02$.

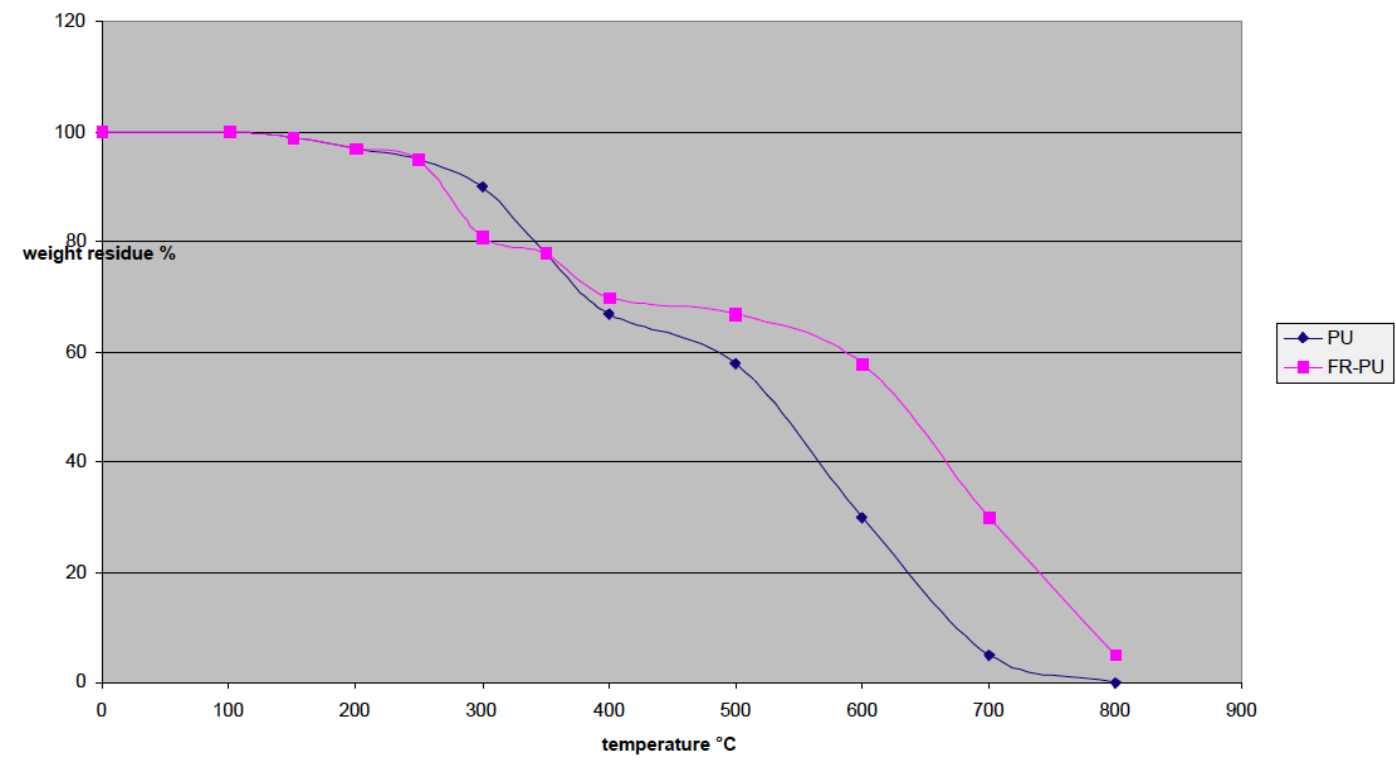

Figure 3: TGA of rigid foam PU and the rigid foam with 12,4\% ammonium polyphosphate FR-PU under air at $10 \mathrm{Kmin}$ heating rate, after differentiation $\mathrm{PU}$ maxima $350^{\circ} \mathrm{C}$ at $65 \%$ residue and $550^{\circ} \mathrm{C}$ at $0 \%$ residue, FR-PU $280^{\circ} \mathrm{C}$ at $80 \%$ residue, $320^{\circ} \mathrm{C}$ at $70 \%$ residue and $650^{\circ} \mathrm{C}$ at $0 \%$ residue.

B2 classification was achieved according DIN 4102.

During manufacturing the $\mathrm{NCO}$ consumption $\mathrm{c}_{1}$, the temperature $\mathrm{T}$, the viscosity $\mathrm{v}$ and the expansion $\mathrm{b}$ were measured. The data were summarized in Table $\mathbf{5}$.

\section{Polyisocyanurate Foam}

Polyisocyanurate foam PIR comprised the very stable and heat resistant isocyanurate ring.

In Table 6 the formulation for $35 \mathrm{~kg} / \mathrm{m}^{3}$ PIR foam was given.

To the PIR formulation $4.9 \%$ liquid trisbutoxyethylphosphate TBEP were added as flame retardant. TBEP decomposed at $300^{\circ} \mathrm{C}$ under evolution of $1240 \mathrm{ml} / \mathrm{g}$ gases or $532 \mathrm{ml} / \mathrm{g}$ water vapour.

$\mathrm{V}_{\mathrm{gas}}=10.5 * 22400 *(1+300 / 273) / 398=1240 \mathrm{ml} / \mathrm{g}$ gases

$\mathrm{V}_{\mathrm{gas}}=4.5 * 22400 *(1+300 / 273) / 398=532 \mathrm{ml} / \mathrm{g}$ water vapour equ. 12

The foams with and without $4.9 \%$ TBEP were subdued a Cone calorimeter test at $50 \mathrm{~kW} / \mathrm{m}^{2}$ heat flux. PIR exerted a heat release rate of $200 \mathrm{~kW} / \mathrm{m}^{2}$ and FR$\mathrm{PIR}$ a heat release rate of $120 \mathrm{~kW} / \mathrm{m}^{2}$.

A B1 classification was achieved and the weight loss was $5 \%$ according to ASTM D-3014.

The manufacture was performed in lab scale. The NCO content $c_{1}$, the temperature $T$, the viscosity $v$ and 
Table 5: Experimental Data of PU-FR (12.4\%APP)

\begin{tabular}{|c|c|c|c|c|c|}
\hline$t \min$ & $c_{1} \mathbf{w} \%$ & U & $\lg v \mathrm{~Pa}^{*} \mathrm{~s}$ & $\mathrm{~T}^{\circ} \mathrm{C}$ & b \\
\hline 0 & 16 & 0 & -0.3 & 25 & 0 \\
\hline 2 & 6.5 & 0.59 & 3.6 & 123 & 30 \\
\hline 3 & 4.5 & 0.72 & 4 & 145 & 23 \\
\hline 5 & 3 & 0.81 & 4.4 & 150 & 24.5 \\
\hline 6 & 2.5 & 0.84 & 4.43 & 151 & 25 \\
\hline 7 & 2 & 0.87 & 4,46 & 152 & 25.5 \\
\hline 8 & 1.5 & 0.91 & 4,5 & 153 & 26 \\
\hline
\end{tabular}

Table 6: Formulation of polyisocyanurate foam PIR and PIRFR

\begin{tabular}{|c|c|c|c|c|c|c|}
\hline Ingredients & Company & parts & Formula & EW & $\mathbf{E}$ & $\%$ \\
\hline Castor oil & Bayer & 4.5 & $\mathrm{CH}_{3}\left(\mathrm{CH}_{2}\right)_{5} \mathrm{CHOHCH}{ }_{2} \mathrm{CH}=\mathrm{CH}\left(\mathrm{CH}_{2}\right)_{7}-\mathrm{COOH}$ & 351 & 0.01 & \\
\hline Lupranol 3602 & BASF & 50.1 & $\left(\mathrm{C}_{3} \mathrm{H}_{6} \mathrm{O}\right)_{3}$ & 148 & 0.34 & \\
\hline Glycerol & & 2.1 & $\mathrm{C}_{3} \mathrm{H}_{8} \mathrm{O}_{3}$ & 30.7 & 0.07 & \\
\hline OS 710 & Bayer & 5.1 & & & & \\
\hline $\mathrm{HHT}$ & BASF & 0.9 & & & & \\
\hline Pentane & Haltermann & 26.7 & & & $\mathrm{C}_{03}$ & 7 \\
\hline Caradate 30 & Shell & 267.5 & $\mathrm{C}_{8} \mathrm{H}_{6} \mathrm{NO}$ & 132 & $2.027 \mathrm{c}_{01}$ & 22 \\
\hline \multirow{3}{*}{ TBEP } & Sum & 358.7 & & & & \\
\hline & Clariant & 18.3 & & & CTBEP & 4,9 \\
\hline & Sum & 377 & & & & \\
\hline
\end{tabular}

Isocyanate index $=2.027 / 0.42=4.83$.

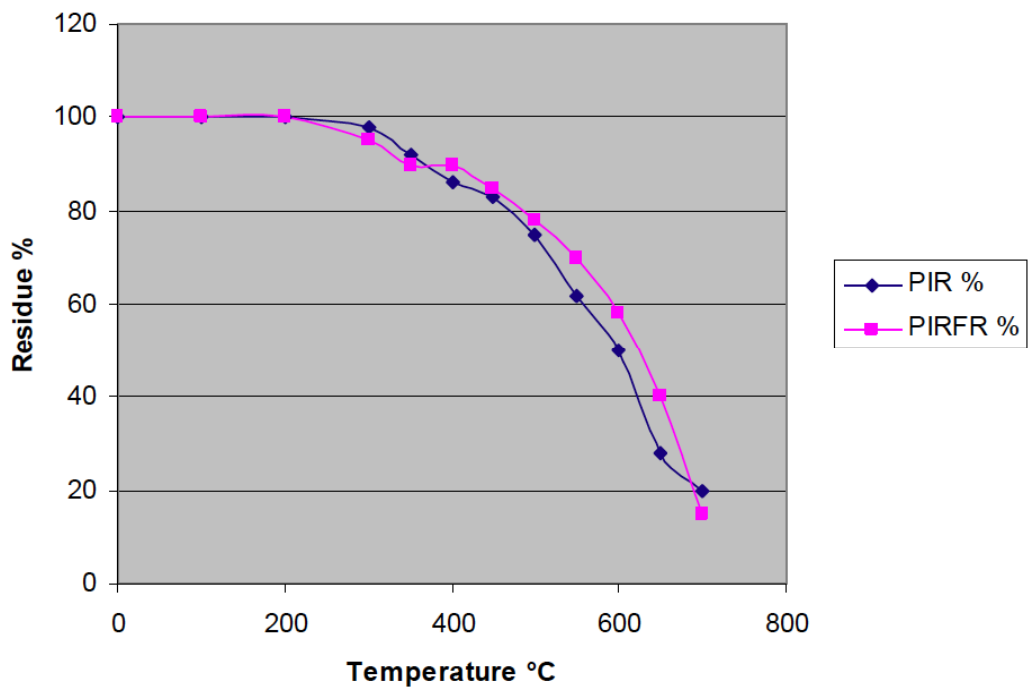

Figure 4: TGA of PIR foam without and with $4.9 \%$ TBEP under air at $5 \mathrm{~K} / \mathrm{min}$ heating rate, after differentiation PIR maxima $350^{\circ} \mathrm{C}$ at $80 \%$ residue, $550^{\circ} \mathrm{C}$ at $50 \%$ residue and $700^{\circ} \mathrm{C}$ at $10 \%$; residue $\mathrm{FR}-\mathrm{PIR} 350^{\circ} \mathrm{C}$ at $90 \%$ resiue, $600^{\circ} \mathrm{C}$ at $60 \%$ residue and $700^{\circ} \mathrm{C}$ at $10 \%$ residue. 
Table 7: Experimental Data of FR-PIR (4.9\%TBEP)

\begin{tabular}{|c|c|c|c|c|c|}
\hline$t \min$ & $c_{1} w \%$ & U & $\mathrm{T}^{\circ} \mathrm{C}$ & Igv $\mathrm{Pa}^{*} \mathrm{~s}$ & b \\
\hline 0 & 22 & 0 & 25 & -0.3 & 0 \\
\hline 2 & 7.5 & 0.63 & 150 & 3.9 & 31 \\
\hline 3 & 5.2 & 0.72 & 168 & 4.34 & 32.5 \\
\hline 5 & 4 & 0.81 & 186 & 4.66 & 34 \\
\hline 6 & 3.3 & 0.84 & 191 & 4.74 & 34 \\
\hline 7 & 2.9 & 0.86 & 195 & 4.81 & 34 \\
\hline 8 & 2.5 & 0.87 & 199 & 4.88 & 34 \\
\hline
\end{tabular}

the expansion b were continuously registered and reproduced in Table 7 .

\section{FOAMING MODEL}

In polyurethane foam production the formulations defined the streams $A$ (components with $\mathrm{NCO}$ reactive groups) and B (components with isocyanate groups). The volume streams determined the isocyanate index and the initial concentration co1 of isocyanate as well as the initial concentration $\mathrm{co} 2$ of water.

\section{Conversion U}

The conversion $U$ of isocyanate over the time $t$ followed a first order reaction with the velocity constant $\mathrm{k}_{1}\left(\min ^{-1}\right)$.

$\mathrm{U}=1-1 /\left(\mathrm{k}_{1} * \mathrm{c}_{01} * \mathrm{t}-1\right)$

equ. 1

$\mathrm{c}_{1}=\mathrm{c}_{01} /\left(\mathrm{k}_{1} * \mathrm{c}_{01} * \mathrm{t}+1\right)=\mathrm{c}_{01} *(1-\mathrm{U})$

equ. 13

\section{Heat of Reaction $\mathrm{h}(\mathrm{kJ} / \mathrm{g})$}

The heat of reaction $\mathrm{h}$ depended on the NCO group with $42 \mathrm{~g} / \mathrm{mole}$ equivalent weight and $50 \mathrm{~kJ} / \mathrm{mole}$ bond energy, the initial isocyanate concentration co1 and the conversion $U$.

$h=50 * \operatorname{co} 1^{*} \mathrm{U} /(42 * 100)=11.9 * \operatorname{co} 1^{*} \mathrm{U}(\mathrm{kJ} / \mathrm{kg})$

equ. 2

\section{Temperature $\mathrm{T}\left({ }^{\circ} \mathrm{C}\right)$}

The temperature increase was calculated according to Kirchhoff.
$\mathrm{T}(\mathrm{K})=298+\mathrm{h} / \mathrm{Cp}=298+50 * \mathrm{c}_{01} * \mathrm{U} /\left(\mathrm{Cp}^{* 4.2}\right)$

$=298+9.52 * \mathrm{c}_{01} * \mathrm{U}$

$\mathrm{T}\left({ }^{\circ} \mathrm{C}\right)=25+9.52^{*} \mathrm{C}_{01}{ }^{*} \mathrm{U}$

equ. 14

For the specific heat of foams $\mathrm{Cp}=1.25 \mathrm{~kJ} /\left(\mathrm{kg}^{*} \mathrm{~K}\right)$ was introduced.

\section{Foam Expansion by Water Reaction $b_{1}$}

Assuming that the water concentration $\mathrm{C}_{02}$ decreased at the same rate as the isocyanate reaction with conversion $U$ equation 15 for expansion by water was obtained.

$$
\begin{aligned}
& \mathrm{b}_{1}=\left(\mathrm{d}_{0} / \mathrm{d}_{\mathrm{f}}-1\right)=\mathrm{R} * \mathrm{~T} * \mathrm{~d}_{0} * \mathrm{c}_{02} * \mathrm{U} /\left(100 * \mathrm{MW}_{\mathrm{H} 2 \mathrm{O}} * \mathrm{p}_{\mathrm{at}}\right) \\
& =0.0456 * \mathrm{c}_{02} * \mathrm{U} * \mathrm{~T}(\mathrm{~K}) \\
& \mathrm{b}_{1}=0.0456 * \mathrm{c}_{02} * \mathrm{U} *\left(298+9.52 * \mathrm{c}_{01} * \mathrm{U}\right)
\end{aligned}
$$

$\mathrm{R}$ the ideal gas constant $82 \mathrm{~cm}^{3 *} \mathrm{bar} /\left(\mathrm{K}^{*} \mathrm{~mole}\right)$ and $\mathrm{MW}_{\mathrm{H} 2 \mathrm{O}}$ water molecular weight $18 \mathrm{~g} / \mathrm{mole}$.

\section{Foam Expansion by Physical Blowing Agent $b_{3}$}

For the auxiliary physical blowing agent $\mathrm{n}$-pentane with the concentration $c_{03}$ the expansion $b_{3}$ was calculated:

$\mathrm{b}_{3}=\mathrm{R}^{* \mathrm{~T}} * \mathrm{~d}_{0} *\left(\mathrm{c}_{03}-\mathrm{c}_{\mathrm{L} 3}\right) /\left(100 * \mathrm{MW}_{3} * \mathrm{p}_{\mathrm{at}}\right)$

$\mathrm{I}=0.0114 *\left(\mathrm{c}_{03}-\mathrm{c}_{\mathrm{L} 3}\right) * \mathrm{~T}(\mathrm{~K})$

equ. 16

Pentane with molecular weight $\mathrm{MW}_{3}=72 \mathrm{~g} / \mathrm{mole}$ and heat of evaporation from polyurethane $\mathrm{Hv}=24 \mathrm{~kJ} / \mathrm{mole}$ dissolved in polyurethane with $\mathrm{C}_{\mathrm{L} 3}$ dissolved pentane according equation 17 . 
$\left.\operatorname{lgc}_{\mathrm{L} 3}=\mathrm{H}_{\mathrm{v}} /(2.3 * \mathrm{R}) * 1000 / \mathrm{T}\right)=1.312 *(1000 / \mathrm{T})-3.6$ $\mathrm{c}_{\mathrm{L} 3}=20.5^{(1000 / \mathrm{T})} / 4000$

equ. 17

After introducing the equations for $c_{L 3}$ and $T$ in $b_{3}$ equation 18 was obtained

$\mathrm{b}_{3}=0.0114 *\left(\mathrm{c}_{03}-20.5^{(1000 / 298)} / 4000\right) *\left(298+9.52 * \mathrm{c}_{01} * \mathrm{U}\right)$

equ. 18

By evaporation the formulation was cooled. The temperature reduction $\mathrm{dT}$ was small, so that this influence was neglected.

$\mathrm{dT}=\mathrm{H}_{\mathrm{v}} *\left(\mathrm{c}_{03}-\mathrm{c}_{\mathrm{L} 3}\right) / \mathrm{Cp}=24 *\left(\mathrm{c}_{03}-\mathrm{c}_{13}\right) /(100 * 1.25)=0.192 *\left(\mathrm{c}_{03}-\mathrm{c}_{\mathrm{L} 3}\right)$ $\mathrm{dT}($ rigid foam $)=0.192 *(3.4-0.23)=0.6 \mathrm{~K}$

$\mathrm{dT}($ isocyanurate foam $)=0.192 *(7.1-0.01)=1.4 \mathrm{~K}$

equ. 19

\section{Viscosity $\mathbf{v}\left(\mathrm{Pa}^{*} \mathbf{s}\right)$}

The viscosity $v$ for the formulations in the liquid state and after solidification the elastic modulus $E$ for the cured foam were determined with the equations 3 and 20.

$\mathrm{v}=\mathrm{v}_{0} * \mathrm{k}_{2}{ }^{\mathrm{U}}$

equ. 3

The initial viscosity of the formulation was vo. $k_{2}\left(\mathrm{~Pa}^{*} \mathrm{~s}\right)$ was a constant for each formulation.

$\mathrm{E}=2 * 3.14 * f * \mathrm{v}$

equ. 20

The frequency of oscillation $f$ and the viscosity after curing $v$ determined the modulus of elasticity $E$. In the case of $\mathrm{f}=0.5 \mathrm{Hertz}$ the elastic modulus $E$ is equivalent with $3.14^{*} \mathrm{v}$.
In Table 8 the data of CMHR for the NCO content $\mathrm{c}_{1}$, the conversion $\mathrm{U}$, the viscosity $\mathrm{v}$, the temperature $\mathrm{T}$ and the expansion $b$ were collected, which had been determined with the help of the foaming model.

In Table 9 the balances of weight and heats were established taking into account $50 \mathrm{~kJ} / \mathrm{mole}$ for the energy of the isocyanate group. The thermodynamic model correlated with TGA and DSC data.

\section{RESULTS}

The physical properties of the manufactured foams were tested and summarized in Table $\mathbf{1 0 .}$

The burning behaviour of the rigid foams was characterized by the weight loss of the foam according to ASTM D- 3014, the combustion of the soft foams by the LOI value and BS 5852 Part 2 (allowed weight loss $6 \%$, flame extinguished after 10 minutes, no smoke after 60 minutes). The Cone calorimeter measurements RHR indicated the positive influence of the flame retardants. The mechanical properties of the cellular plastics were characterized by the tensile strength (Tensile Str.), the compressive strength (Comp. Str.) and the elastic modulus (E-modulus) calculated from the viscosity $v$ after 10 minutes.

The physical properties of the flame retardants were summarized in Table 11.

In Figure $\mathbf{5}$ and $\mathbf{6}$ the calculated and experimental values were compared for $\mathrm{b}, \mathrm{T}, \mathrm{v}$ and $\mathrm{NCO}$ concentration.

Table 8: Calculated Data for CMHRF k1= $0.08 \mathrm{~min}^{-1}, \operatorname{lgk} 2=2.8 \mathrm{~Pa}{ }^{*} \mathrm{~s}, \mathrm{co} 2=2 \%$

\begin{tabular}{|c|c|c|c|c|c|}
\hline$t \min$ & $c_{1} w \%$ & $\mathbf{U}$ & Igv $\mathrm{Pa}^{*} \mathrm{~s}$ & $\mathbf{T}^{\circ} \mathrm{C}$ & $b_{1}$ \\
\hline 0 & 12 & 0 & -0.3 & 25 & 0 \\
\hline 1 & 6.1 & 0.49 & 1.13 & 81 & 15.8 \\
\hline 2 & 4.1 & 0.66 & 1.55 & 100.5 & 22.5 \\
\hline 3 & 3.1 & 0.74 & 1.8 & 109.5 & 28 \\
\hline 4 & 2.5 & 0.79 & 1.9 & 120 & 29.8 \\
\hline 5 & 2 & 0.83 & 2 & 122 & 30.6 \\
\hline 6 & 1.8 & 0.85 & 2.1 & 124.5 & 31.5 \\
\hline 7 & 1.6 & 0.87 & 2.15 & 125.5 & 32 \\
\hline 8 & 1.4 & 0.88 & 2.2 & 128 & 32.9 \\
\hline 9 & 1.3 & 0.9 & 2.2 & 128 & 32.9 \\
\hline 10 & 1.1 & 0.91 & 2.25 & 129 & 33.4 \\
\hline
\end{tabular}

$C_{1}=12 /\left(k_{1}{ }^{*} C_{01}{ }^{*} t+1\right) ; U=\left[1-1 /\left(k_{1}{ }^{*} C_{01}{ }^{*} t+1\right)\right] ; \lg v=-0.3+U^{*} \operatorname{lgk}_{2} ; b_{1}=0.0912^{*} U^{*}\left(273+T^{\circ} C\right)$. 
Table 9: Balance of Weight and Heat for Synthesis, Combustion and Decomposition for HR (EW =147g/mole) and Isocyanate Reaction Heat $\mathrm{H}=50 \mathrm{~kJ} / \mathrm{mole}$

Synthesis:

Water

$$
\begin{array}{rl}
\mathrm{h} & =-0.64 \mathrm{~kJ} / \mathrm{g} \\
\mathrm{F} 1: 0.222\left(2 \mathrm{C}_{4.5} \mathrm{H}_{3} \mathrm{NO}+\mathrm{H}_{2} \mathrm{O}=\right. & \left.\mathrm{CO}_{2}+\mathrm{C}_{8} \mathrm{H}_{8} \mathrm{~N}_{2} \mathrm{O}\right) \\
\mathrm{MW}: 2 * 87+18=44+148 & 0.222 *-0.64=-0.141 \mathrm{~kJ} / \mathrm{g} \\
2 *-133.5-286-100 & =-393.5-259.5
\end{array}
$$

Polyole

$$
\begin{gathered}
\mathrm{h}=-0.32 \mathrm{~kJ} / \mathrm{g} \\
\mathrm{F} 2: 0,054\left[\left(\mathrm{C}_{3} \mathrm{H}_{6} \mathrm{O}\right)_{32}+\mathrm{C}_{4.5} \mathrm{H}_{3} \mathrm{NO}=\mathrm{C}_{100.5} \mathrm{H}_{195} \mathrm{NO}_{33}\right] \quad 0.054 *-0.32=-0.017 \mathrm{~kJ} / \mathrm{g}
\end{gathered}
$$$$
\text { MW: } 1856+87=1943
$$

H: $-32 *-325.5-133.5-50=-10279.5$

Chain extender

$$
\begin{aligned}
& \mathrm{h}=-0.32 \mathrm{~kJ} / \mathrm{g} \\
& \text { F3:0.057( } \left.1 / 3 \mathrm{C}_{4} \mathrm{H}_{11} \mathrm{NO}_{2}+\mathrm{C}_{4,5} \mathrm{H}_{3} \mathrm{NO}=\mathrm{C}_{5.83} \mathrm{H}_{6.67} \mathrm{~N}_{1.33} \mathrm{O}_{1.67}\right) \\
& \text { MW: } 35+87=122 \\
& \text { H: } 1 / 3 *-646-133.5-50=-348.5
\end{aligned}
$$

Isocyanurate

$$
\mathrm{h}=-0.32 \mathrm{~kJ} / \mathrm{g}
$$

F4:(0.583 -0.444- 0.054-0.057)* $\mathrm{C}_{4.5} \mathrm{H}_{3} \mathrm{NO}=\left(\mathrm{C}_{4.5} \mathrm{H}_{3} \mathrm{NO}\right) \mathrm{pol}$

H: $-133.5-50=-233.5$

$$
\begin{array}{r}
0.028 *-0.32=-0.010 \mathrm{~kJ} / \mathrm{g} \\
\text { sum: }-0.185 \mathrm{~kJ} / \mathrm{g}
\end{array}
$$

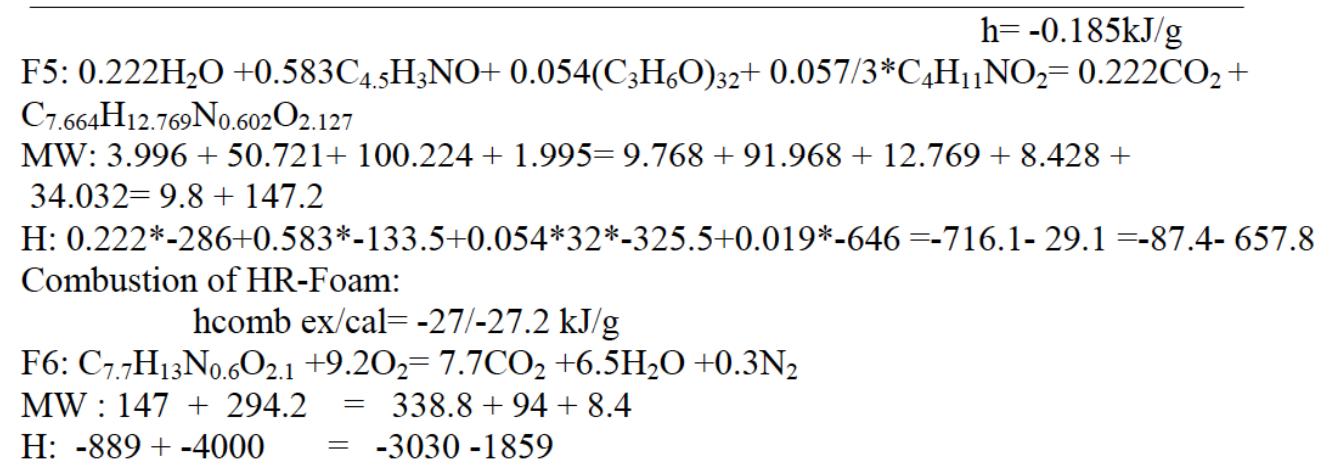

In DSC investigation under nitrogen HR- Foam decomposed and two peaks were observed: peak 1 reached from $250-350^{\circ} \mathrm{C}$ with $0.3 \mathrm{~kJ} / \mathrm{g}$ heat consumption and peak 2 from $350-420^{\circ} \mathrm{C}$ with $0.7 \mathrm{~kJ} / \mathrm{g}$ heat consumption. In the following the decomposition was described by balances.

Decomposition of HR-Foam:

Chain extender

$270^{\circ} \mathrm{C} \mathrm{h}=0.68 \mathrm{~kJ} / \mathrm{g}$

F7: $0.057 *\left(\mathrm{C}_{5.8} \mathrm{H}_{6.7} \mathrm{~N}_{1,3} \mathrm{O}_{1.7}=(1 / 3) * \mathrm{C}_{4} \mathrm{H}_{11} \mathrm{NO}_{2}+\mathrm{C}_{4.5} \mathrm{H}_{3} \mathrm{NO}\right) \quad 0.57 * 0.68=0.039$

MW: $122=35+87$

H: $-398.5+100=-215-133.5$

$310^{\circ} \mathrm{C} \mathrm{h}=0,95 \mathrm{~kJ} / \mathrm{g}$, Loss $=1,4 \%, \mathrm{R}=98,6 \%$

F8: $0.019 *\left(\mathrm{C}_{4} \mathrm{H}_{11} \mathrm{NO}_{2}=\mathrm{NH}_{3}+2 \mathrm{H}_{2} \mathrm{O}+2 \mathrm{C}_{2} \mathrm{H}_{2}\right)$

$0.019 * 0.95=0.018$

MW: $105=17+36+52$

$\mathrm{H}:-215+139=-46-2 * 242+454$

Polyurethane

$320^{\circ} \mathrm{C} \mathrm{h}=0.68 \mathrm{~kJ} / \mathrm{g}$

F9: $0.054 *\left(\mathrm{C}_{100.5} \mathrm{H}_{195} \mathrm{O}_{33} \mathrm{~N}=\mathrm{C}_{4.5} \mathrm{H}_{3} \mathrm{NO}+\left(\mathrm{C}_{3} \mathrm{H}_{6} \mathrm{O}\right)_{32}\right) \quad 0.054 * 0.68=0.037$ 
MW: $\quad 1943=87+1856$

H: $-10329.5+100=-133.5-(32 * 315.5=10096)$

Polyole

$330^{\circ} \mathrm{C} \mathrm{h}=0.116$

F10: $0.054 *\left[\left(\mathrm{C}_{3} \mathrm{H}_{6} \mathrm{O}\right)_{32}=32 \mathrm{C}_{3} \mathrm{H}_{6} \mathrm{O}\right]$

$0.054 * 0.116=0.006$

MW: $1856=32 * 58$

$\mathrm{H}:-315.5+17=-298.5$

$340^{\circ} \mathrm{C} \mathrm{h}=0.34 \mathrm{~kJ} / \mathrm{g}$, Loss $=68.2 \%, \mathrm{R}=30,4 \%$

F11: $0.054 * 16\left(2 \mathrm{C}_{3} \mathrm{H}_{6} \mathrm{O}\right)=16 \mathrm{C}_{6} \mathrm{H}_{12} \mathrm{O}_{2}$ gas $)$

MW: $2 * 58=116$

$\mathrm{H}: 2 *-298.5+50=-547$

peak1 $270-340^{\circ} \mathrm{C}$

$0.054 * 32 * 0.34=0.588$

Polyurea

$335^{\circ} \mathrm{C} \mathrm{h}=0.68 \mathrm{~kJ} / \mathrm{g}$

F12: $0.222 *\left(\mathrm{C}_{8} \mathrm{H}_{8} \mathrm{~N}_{2} \mathrm{O}=\mathrm{C}_{3,5} \mathrm{H}_{5} \mathrm{~N}+\mathrm{C}_{4,5} \mathrm{H}_{3} \mathrm{NO}\right)$

$0.69 \mathrm{~kJ} / \mathrm{g}, \mathrm{R}=30.4 \%$

MW: $148=61+87$

$\mathrm{H}: \quad-359.5+100=-26-133.5$

Amine

$350^{\circ} \mathrm{C} \mathrm{h}=0.20 \mathrm{~kJ} / \mathrm{g}$, Loss $=9.2 \%, \mathrm{R}=21,2 \%$

F13: $0.222 *\left(\mathrm{C}_{3.5} \mathrm{H}_{5} \mathrm{~N}=0.5 \mathrm{C}_{6} \mathrm{H}_{6}+0.5 \mathrm{CH}_{4}+0.5 \mathrm{~N}_{2}\right)$

$0.222 * 0.20=0.044$

MW: $61=39+8+14$

$\mathrm{H}:-26+28.75=41.5-0.5 * 87.5$

Isocyanate

$380^{\circ} \mathrm{C} \quad \mathrm{h}=0.44 \mathrm{~kJ} / \mathrm{g}$, Loss $=19,9 \%, \mathrm{R}=1.3 \%$ Loss, $1.5 \%$

F14: $(0.583-0.222) *\left(\mathrm{C}_{4.5} \mathrm{H}_{3} \mathrm{NO}=0.5 \mathrm{C}_{6} \mathrm{H}_{6}+\mathrm{CO}+0.5 \mathrm{~N}_{2}+0.5 \mathrm{C}\right) \quad 0.361 * 0.44=0.157$

MW: $\quad 87=39+28+14+6$

$\mathrm{H}: \quad-133.5+64=-41.5-111$

peak2 $325-400^{\circ} \mathrm{C} \quad 0.35 \mathrm{~kJ} / \mathrm{g}, \overline{\mathrm{R}}=1,5 \%$ sum: $1.04 \mathrm{~kJ} / \mathrm{g}$

Summarized hdec $=1.06 \mathrm{~kJ} / \mathrm{g}, \mathrm{R}=1.6 \%$

F15: $\mathrm{C}_{7.7} \mathrm{H}_{13} \mathrm{~N}_{0.6} \mathrm{O}_{2.1}=0.764 \mathrm{C}_{6} \mathrm{H}_{12} \mathrm{O}_{2}+0.306 \mathrm{C}_{6} \mathrm{H}_{6}+0.019 \mathrm{NH}_{3}+0.195 \mathrm{C}+0.389 \mathrm{CO}+$

$0.111 \mathrm{CH}_{4}+0.038 \mathrm{C}_{2} \mathrm{H}_{2}+0.306 \mathrm{~N}_{2}+0.038 \mathrm{H}_{2} \mathrm{O}$

MW: $147=100.2+23.9+0.3+2.3+10.9+1.8+1.0+8.6+0.7=149.6$

H: $-657.8+146.2=-472.6+25.4-0.9-43.2-9.7+8.6-9.2=501.6$

Table 10: Physical Properties of Foams

\begin{tabular}{|c|c|c|c|c|c|c|c|}
\hline Type & HRF & CMHR & CM & PU & PUFR & PIR & PIRFR \\
\hline FR & 0 & $22.3 \% \mathrm{M}$ & 43\%ATH & 0 & $12.4 \%$ APP & 0 & 4.9TВEP \\
\hline $\mathrm{MW}(\mathrm{g} / \mathrm{mole})$ & 147 & 147 & 147 & 266 & 266 & 324 & 324 \\
\hline $\mathrm{Hf}(\mathrm{kJ} / \mathrm{mole})$ & -687 & -687 & -687 & -698 & -698 & -702 & -702 \\
\hline Hf(comb.) & -890 & -890 & -890 & -700 & -700 & -550 & -550 \\
\hline hsynth(kJ/g) & -0.37 & -0.37 & -0.37 & -0.23 & -0.23 & -0.31 & -0.31 \\
\hline hcomb(kJ/g) & -27 & -21 & -14 & -30 & -26 & -30 & -28 \\
\hline Tdec $\mathrm{TGA}{ }^{\circ} \mathrm{C}$ & 280,380 & $250,300,380$ & & 300,600 & $250,300,650$ & $350,550,650$ & $350,600,700$ \\
\hline R\% TGA & 60,10 & $80,50,5$ & & 65,5 & $80,70,5$ & $85,55,10$ & $90,60,10$ \\
\hline $\mathrm{R} \%$ calculated & 30,9 & & & 63,15 & & $84,67,7,5$ & \\
\hline hdec(kJ/g) & $0,69,0,38$ & & & $0,41,0,38$ & & $0,12,0,68,0,57$ & 1,34 \\
\hline density(kg/m3) & 25 & 27 & 45 & 35 & 38 & 30 & 33 \\
\hline Tensile Str.(kPa) & 100 & 80 & 60 & 400 & 360 & 450 & 420 \\
\hline E-moduluskPa(v) & & 31 & & & 120 & & 345 \\
\hline
\end{tabular}




\begin{tabular}{|c|c|c|c|c|c|c|c|}
\hline Type & HRF & CMHR & CM & PU & PUFR & PIR & PIRFR \\
\hline Comp. Str. (kPa) & 1.5 & 2 & & 90 & 120 & 120 & 160 \\
\hline BS5952/2 Crip5 & & Positive & Positive & & & & \\
\hline LOI (K/\%) & & 0.29 & 0.15 & & & & \\
\hline ASTM D-3014 (\%) & & & & 53 & 13 & 25 & 5 \\
\hline $\mathrm{RHRkW} / \mathrm{m} 2$ & $1200 / 50 \mathrm{~kW} / \mathrm{m} 2$ & $500 / 50 \mathrm{~kW} / \mathrm{m} 2$ & & $120 / 5 \mathrm{~kW} / \mathrm{m} 2$ & $40 / 5 \mathrm{~kW} / \mathrm{m} 2$ & 230/50kW/m2 & 120/50kW/m2 \\
\hline
\end{tabular}

Table 11: Physical Properties of Flame Retardants FRs

\begin{tabular}{|ccccc|}
\hline & M & ATH & APP & TBEP \\
\hline \hline MW g/mole & 126 & 156 & 97 & 398 \\
$\mathrm{hcomb}(\mathrm{kJ} / \mathrm{g})$ & -15.6 & 0 & -3.5 & -27.9 \\
$\mathrm{Hf}(\mathrm{kJ} / \mathrm{mole})$ & -72 & -2564 & -961 & -2317.5 \\
$\mathrm{Tdec}\left({ }^{\circ} \mathrm{C}\right)$ & 350 & 300 & 350 & 300 \\
$\operatorname{hdec}(\mathrm{kJ} / \mathrm{g})$ & 1.0 & 1.2 & 2.5 & 3.2 \\
Vgas $(\mathrm{ml} / \mathrm{g})$ & $419 \mathrm{Mgas}$ & $452 \mathrm{H}_{2} \mathrm{O}$ & $790 \mathrm{H}_{2} \mathrm{O}_{2} \mathrm{NH}_{3}$ & $1247 \mathrm{H}_{2} \mathrm{O}+\mathrm{KW}^{2} 255 \mathrm{H}_{2} \mathrm{O}$ \\
Residue $(\%)$ & 0 & $65 \mathrm{Al}_{2} \mathrm{O}_{3}$ & $73.2 \mathrm{P}_{2} \mathrm{O}_{5}$ & $18 \mathrm{P}_{2} \mathrm{O}_{5}$ \\
\hline
\end{tabular}

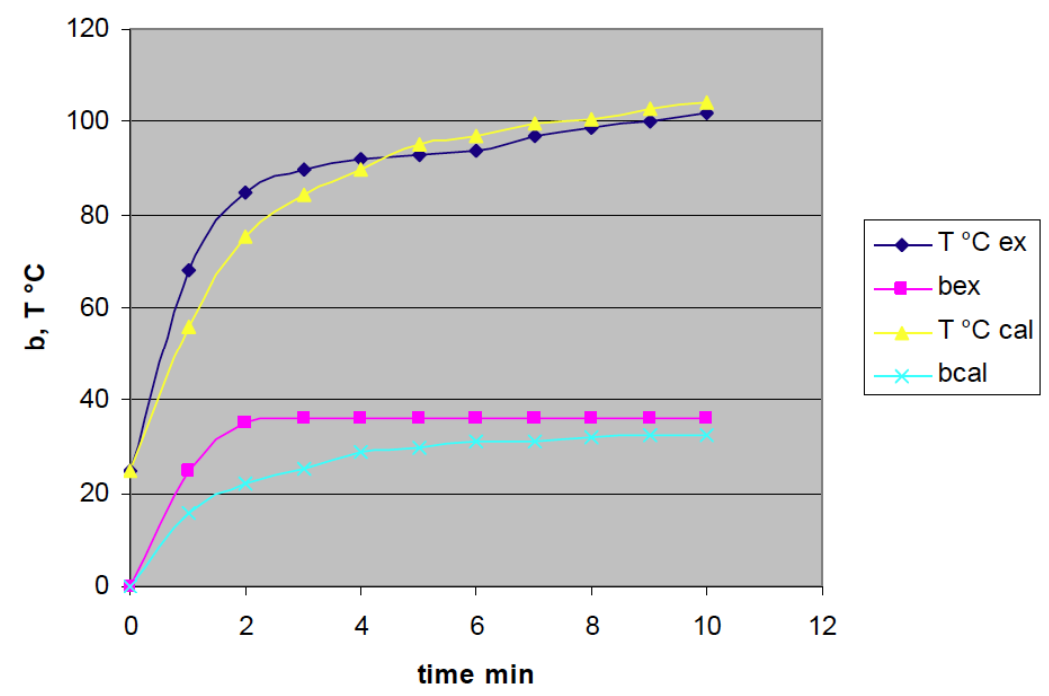

Figure 5: Comparison of experimental and calculated temperatures $T$ and expansions b for CMHR- foam.

The highest discrepancy between calculated and experimental data was observed for the expansion $b$ in Figure 5. The reason for this was the circumstance that only one constant $k_{1}$ was used for the isocyanate consumption. No account was taken for the fact that different reactions occurred for the formation of urethane, urea, isocyanurate and carbodiimide. Also the balances of heat were accomplished with only $50 \mathrm{~kJ} / \mathrm{mole}$ as overall isocyanate heat of reaction. Nevertheless the agreement with experimental data was good. CIM caused a high effort of analytical and measuring equipment. But the higher expenditure was rewarded by better understanding and lead to better products at lower cost. In Table 12 the inputs for model calculation were summarized. More sophisticated models were thinkable but would complicate the calculations.

\section{CONCLUSION}

FR-polyurethane foams were described by chemical formulas. The flame retardants were applied in such concentrations that as predominant reaction decomposition as under nitrogen the achievable optimum took place. A kinetic foaming model was established as well as balances of weight and heat of formation were set up, which described foam synthesis, combustion and decomposition giving the chemical background for CIM. 


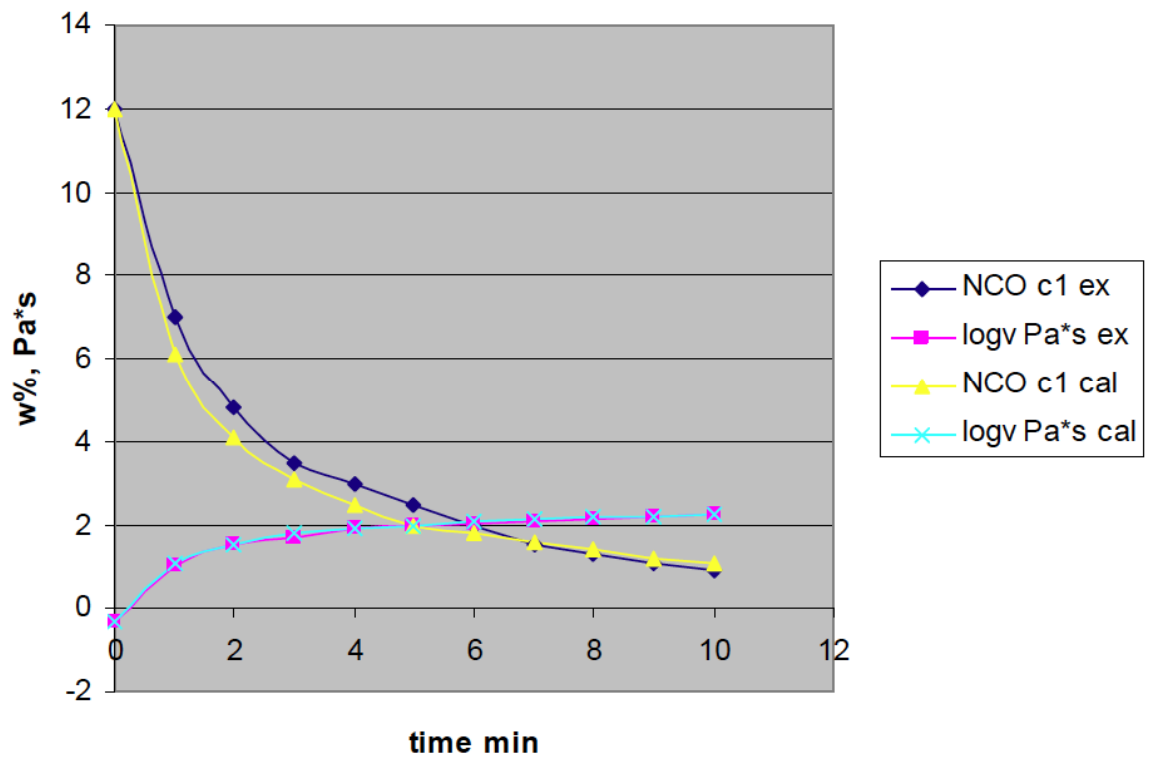

Figure 6: Comparison of experimental and calculated \%NCO and viscosity v for CMHR-foam.

Table 12: Input for Model Calculations

\begin{tabular}{|cccc|}
\hline Parameter & CMHR & PU-FR & PIR-FR \\
\hline \hline $\mathrm{C}_{01} \% \mathrm{NCO}$ & 12.0 & 16 & 22.1 \\
$\mathrm{C}_{02} \% \mathrm{H}_{2} \mathrm{O}$ & 2 & 0.6 & 0 \\
$\mathrm{C}_{03} \% \mathrm{n}-\mathrm{Pentane}$ & 0 & 3,4 & 7 \\
$\mathrm{k}_{1}$ min $^{-1}$ & 0.08 & 0.06 & 0.04 \\
lgk $_{2} \mathrm{~Pa}^{*}$ & 2.8 & 5.0 & 6.0 \\
$\% \mathrm{FR}$ & $22.3 \mathrm{M}$ & $12.4 \mathrm{APP}$ & 4.9 TBEP \\
\hline
\end{tabular}

In the foaming model the highest discrepancy was observed for the expansion $b$ in Figure $\mathbf{5}$. The reason for this was to be seen in the circumstance that only one constant for the isocyanate consumption was taken into account for the polyurethane reaction as well as for the urea reaction.

The balances of masses and heats with $50 \mathrm{~kJ} / \mathrm{mole}$ for the isocyanate energy lead to results, which were in good agreement with experimental data.

The balance of heat and weight led to two mean peaks of decomposition from $270-340^{\circ} \mathrm{Cand} 350-$ $400^{\circ} \mathrm{C}$ for CMHR foam as measured by DSC and cited by Dick [13]. The urethane scission and polyole decomposition happened first under $0.7 \mathrm{~kJ} / \mathrm{g}$ heat evolution followed by the urea scission and degradation of amine and isocyanate under $0.4 \mathrm{~kJ} / \mathrm{g}$ heat development.

The calculated heats of combustion $30 \mathrm{~kJ} / \mathrm{g}$ for rigid, $26 \mathrm{~kJ} / \mathrm{g}$ for FR-rigid foam and $30 \mathrm{~kJ} / \mathrm{g}$ for PIR foam were higher than those found in literature with $21 \mathrm{~kJ} / \mathrm{g}$ for PUR, $12 \mathrm{~kJ} / \mathrm{g}$ for FR-PUR and $10 \mathrm{~kJ} / \mathrm{g}$ for PIR [29].

The cited heats of gasification [29]: $1.4 \mathrm{~kJ} / \mathrm{g}$ (DSC) for flexible foam, $1.2-5.3 \mathrm{~kJ} / \mathrm{g}$ (flammability apparatus) for rigid foam and $1.2-6.4 \mathrm{~kJ} / \mathrm{g}$ (flammability apparatus) for polyisocyanurate foam, matched with the calculated heats of decomposition.

CIM was started successfully. The measurements conducted with high expenditure on equipment agreed with those derived from calculations.

The applied flame retardants decomposed near the decomposition temperature of the foams. They evolved non burning gases under heat uptake and enriched the char. The target was to establish computer integrated manufacturing without continuous measurements but by mere calculation. With the knowledge of the velocity constant $\mathrm{k}_{1}$ and the viscosity parameter $\mathrm{k}_{2}$ CIM without continuous measurements was possible. 


\section{APPENDIX}

Table 13: Calculated Data for FR-PU $(12,4 \%$ APP $)$ NCO $=16 \%, c 02=0,6 \%, k 1=0,062 \mathrm{~min}^{-1}$, logk2 $=5 \mathrm{~Pa}^{*} \mathrm{~s}, \mathrm{co3}=3,4 \%$. $\mathrm{dT}=0,6^{\circ} \mathrm{C}$

\begin{tabular}{|c|c|c|c|c|c|c|c|}
\hline$t \min$ & c1 w\% & $\mathbf{U}$ & $\mathbf{T}^{\circ} \mathbf{C}$ & $\lg v \mathrm{~Pa}^{*} \mathrm{~s}$ & b1 & b3 & $b 1+b 3$ \\
\hline 0 & 16 & 0 & 25 & $-0,3$ & 0 & 0 & 0 \\
\hline 2 & 5,4 & 0,67 & 125 & 3,05 & 7,2 & 11,8 & 18 \\
\hline 3 & 4,1 & 0,75 & 137 & 3,45 & 8,3 & 12,6 & 20,9 \\
\hline 5 & 2,7 & 0,84 & 150,5 & 3,9 & 9,6 & 13,5 & 23,1 \\
\hline 6 & 2,3 & 0,86 & 154 & 4 & 10,1 & 13,6 & 23,7 \\
\hline 7 & 2 & 0,88 & 157 & 4,1 & 10,3 & 13,7 & 24 \\
\hline 8 & 1,8 & 89 & 160 & 4,15 & 10,5 & 13,8 & 24,3 \\
\hline
\end{tabular}

Table 14: Balance of Weight and Heat for Synthesis, Combustion and Decomposition of RF (EW=266) and Isocyanate Reaction Heat $\mathrm{H}=50 \mathrm{~kJ} / \mathrm{mole}$

Synthesis:

Water reaction $\quad \mathrm{h}=-0,369 \mathrm{~kJ} / \mathrm{g}$

$0,111 *\left(2 \mathrm{C}_{8} \mathrm{H}_{6} \mathrm{NO}+\mathrm{H}_{2} \mathrm{O}=\mathrm{CO}_{2}+\mathrm{C}_{15} \mathrm{H}_{14} \mathrm{~N}_{2} \mathrm{O}\right)$

$0,111^{*}-0,369=-0,041 \mathrm{~kJ} / \mathrm{g}$

MW $264+18=44+238$

H $2 *-91-286-100=-393,5-174,5$

Polyol reaction $\mathrm{h}=-0,185 \mathrm{~kJ} / \mathrm{g}$

$\left.0,925 *\left(\mathrm{C}_{3} \mathrm{H}_{6} \mathrm{O}\right) 1,86+\mathrm{C}_{8} \mathrm{H}_{6} \mathrm{NO}=\mathrm{C}_{13,6} \mathrm{H}_{18} \mathrm{NO}_{2,9}\right)$

$0,925 *-0,185=-0,171 \mathrm{~kJ} / \mathrm{g}$

MW $108+132=240$

H $1,86^{*}-298,5-91-50=-696,2$

Chain extender reaction $\mathrm{h}=-0,554 \mathrm{~kJ} / \mathrm{g}$

$0,086 / 3 *\left(\mathrm{C}_{4} \mathrm{H}_{11} \mathrm{NO}_{2}+3 \mathrm{C}_{8} \mathrm{H}_{6} \mathrm{NO}=\mathrm{C}_{28} \mathrm{H}_{29} \mathrm{~N}_{4} \mathrm{O}_{5}\right)$

MW $\quad 105+3 * 232=501$

H $-646+3 *-91-150=1069$

Isocyanate contribution $\mathrm{h}=-0,185 \mathrm{~kJ} / \mathrm{g}$

$(1,258-0,111-0,925-0,086) \mathrm{C}_{8} \mathrm{H}_{6} \mathrm{NO}=\mathrm{C}_{8} \mathrm{H}_{6} \mathrm{NO}$

$0,025 *-0,185=-0,005$

MW $132=132$

Sum: $-0,233 \mathrm{~kJ} / \mathrm{g}$

$\mathrm{H}=-91-50=-141$

$\mathrm{h}=-0,233 \mathrm{~kJ} / \mathrm{g}$

$0,925\left(\mathrm{C}_{3} \mathrm{H}_{6}\right)_{1,86}+0,0287 \mathrm{C}_{4} \mathrm{H}_{11} \mathrm{NO}_{2}+0,111 \mathrm{H}_{2} \mathrm{O}+1,258 \mathrm{C}_{8} \mathrm{H}_{6} \mathrm{NO}=0,111 \mathrm{CO}_{2}+$

$\mathrm{C}_{15,1} \mathrm{H}_{19,4} \mathrm{~N}_{1,3} \mathrm{O}_{2,7}$

MW: $99,8+3+2+166=270,8=4,9+266$

H: $0,925 * 1,86 *-298,5+0,0287 *-646+0,111 *-286+1,258 *-91-63=-43,68$

$\mathrm{H}-513,6-18,5-31,7-114,5=678,3-63=-740,7=-43,7-697$ 
(Table 14). Continued.

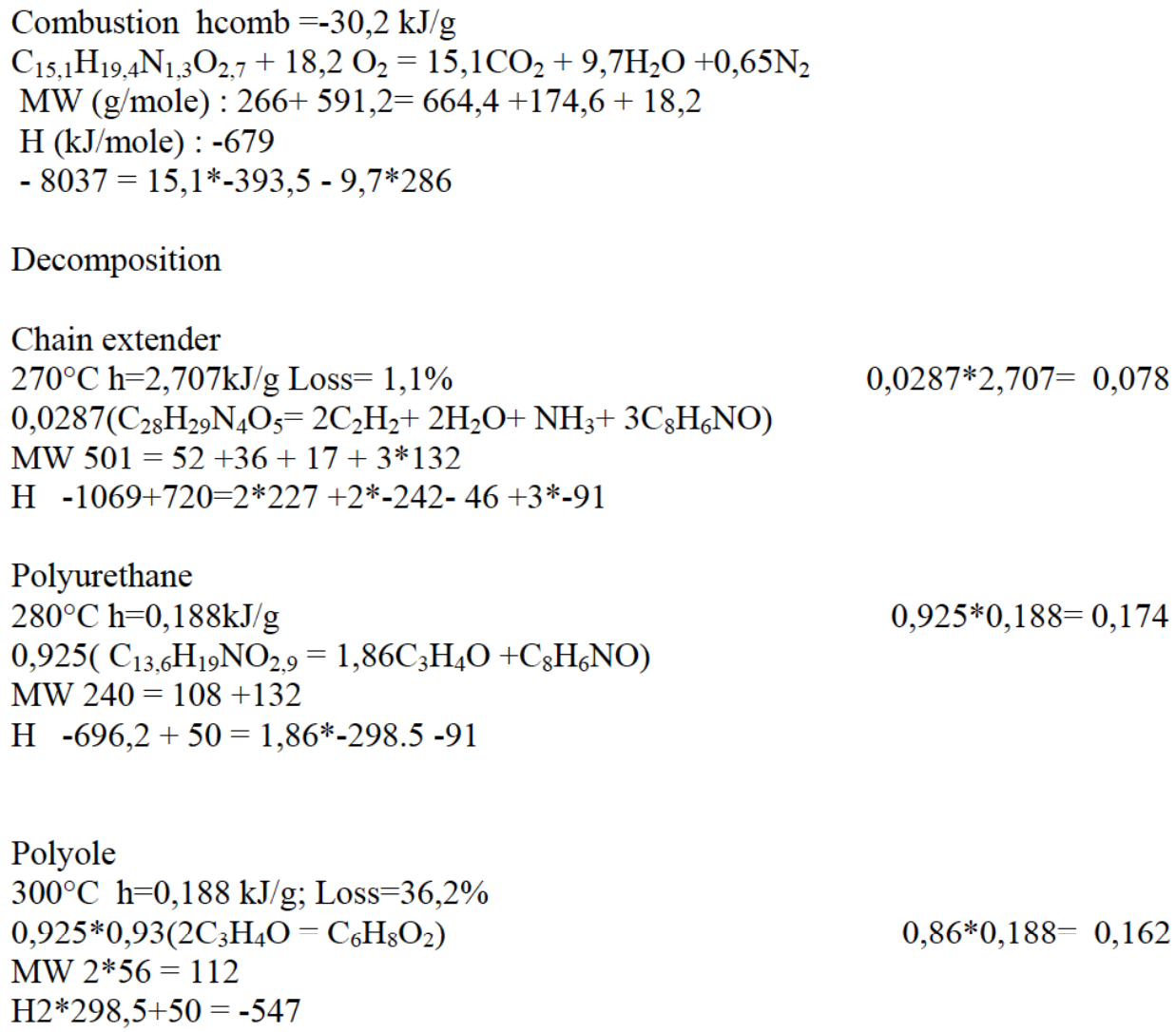

Decomposition

Chain extender

$270^{\circ} \mathrm{C} \mathrm{h}=2,707 \mathrm{~kJ} / \mathrm{g}$ Loss $=1,1 \%$

$0,0287\left(\mathrm{C}_{28} \mathrm{H}_{29} \mathrm{~N}_{4} \mathrm{O}_{5}=2 \mathrm{C}_{2} \mathrm{H}_{2}+2 \mathrm{H}_{2} \mathrm{O}+\mathrm{NH}_{3}+3 \mathrm{C}_{8} \mathrm{H}_{6} \mathrm{NO}\right)$

MW $501=52+36+17+3 * 132$

H $-1069+720=2 * 227+2 *-242-46+3 *-91$

Polyurethane

$280^{\circ} \mathrm{C} \mathrm{h}=0,188 \mathrm{~kJ} / \mathrm{g}$

$0,925\left(\mathrm{C}_{13,6} \mathrm{H}_{19} \mathrm{NO}_{2,9}=1,86 \mathrm{C}_{3} \mathrm{H}_{4} \mathrm{O}+\mathrm{C}_{8} \mathrm{H}_{6} \mathrm{NO}\right)$

MW $240=108+132$

H $-696,2+50=1,86^{*}-298.5-91$

Polyole

$300^{\circ} \mathrm{C} \mathrm{h}=0,188 \mathrm{~kJ} / \mathrm{g} ;$ Loss $=36,2 \%$

$0,925 * 0,93\left(2 \mathrm{C}_{3} \mathrm{H}_{4} \mathrm{O}=\mathrm{C}_{6} \mathrm{H}_{8} \mathrm{O}_{2}\right)$

MW $2 * 56=112$

$\mathrm{H} 2 * 298,5+50=-547$

$0,0287 * 2,707=0,078$

$0,925 * 0,188=0,174$

$0,86 * 0,188=0,162$

Urea

$500^{\circ} \mathrm{C} \quad \mathrm{h}=0,724 \mathrm{~kJ} / \mathrm{g} ;$ Loss $=4,4 \%$

$0,111\left(\mathrm{C}_{15} \mathrm{H}_{14} \mathrm{~N}_{2} \mathrm{O}=\mathrm{C}_{8} \mathrm{H}_{6} \mathrm{NO}+\mathrm{C}_{6} \mathrm{H}_{6}+0,5 \mathrm{C}_{2} \mathrm{H}_{4}+0,5 \mathrm{~N}_{2}\right)$

peak $1 \mathrm{R}=62,7 \% ; \mathrm{h}=0,414 \mathrm{~kJ} / \mathrm{g}, 300^{\circ} \mathrm{C}$

MW $238=132+78+14+14$

H $-174,5+192,5=-91+83+0,5 * 52$

Isocyanate

$600^{\circ} \mathrm{C} \mathrm{h}=0,237 \mathrm{~kJ} / \mathrm{g}$, Loss $=56,8 \%$

$1,258 *\left(\mathrm{C}_{8} \mathrm{H}_{6} \mathrm{NO}=\mathrm{CO}+\mathrm{C}_{6} \mathrm{H}_{6}+0,5 \mathrm{~N}_{2}+\mathrm{C}\right)$

$1,258 * 0,237=0,298$

MW $132=28+78+14+12$

$\mathrm{H}-91+63=-28$

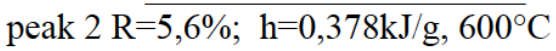
Sum: $0,792 \mathrm{~kJ} / \mathrm{g}$

Summarized $\quad \mathrm{h}=0,601 \mathrm{~kJ} / \mathrm{g}, \mathrm{R}=5,2 \%$

$\mathrm{C}_{15,1} \mathrm{H}_{19} \mathrm{~N}_{1,3} \mathrm{O}_{2,7}=0,925 \mathrm{C}_{6} \mathrm{H}_{8} \mathrm{O}_{2}+1,147\left(\mathrm{CO}+\mathrm{C}_{6} \mathrm{H}_{6}+\mathrm{C}+0,5 \mathrm{~N}_{2}\right)+0,111 \mathrm{C}_{6} \mathrm{H}_{6}+0,055 \mathrm{C}_{2} \mathrm{H}_{4}+$ $0,055 \mathrm{~N}_{2}+0,057 \mathrm{C}_{2} \mathrm{H}_{2}+0,057 \mathrm{H}_{2} \mathrm{O}+0,0287 \mathrm{NH}_{3}$

MW $266=99,8+151,4+8,6+1,4+1,5+1,5+1+0,5$

H $-697+159,8=-506-31,9+9,3+2,9+12,9-13,8-1,3=-537,2$ 
Table 15: Calculated Data for FRPIR (4,9\%TBEP) k1 $=0,04 \mathrm{~min}^{-1}, \operatorname{logk} 2=6 \mathrm{~Pa}^{*} \mathrm{~s}, \mathrm{co3}=7 \%, \mathrm{dT}=1,4^{\circ} \mathrm{C}$

\begin{tabular}{|c|c|c|c|c|c|c|}
\hline$t \min$ & c1 w\% & $\mathbf{U}$ & $\mathrm{T}^{\circ} \mathrm{C}$ & Lgv & cL3 w\% & b3 \\
\hline 0 & 22 & 0 & 30 & $-0,3$ & 7 & 0 \\
\hline 2 & 7,7 & 0,63 & 162 & 3,64 & 0,3 & 34,3 \\
\hline 3 & 6 & 0,72 & 179 & 4,12 & 0,2 & 35,6 \\
\hline 5 & 4 & 0,81 & 200 & 4,59 & 0,15 & 37,7 \\
\hline 6 & 3,5 & 0,84 & 202 & 4,74 & 0,14 & 37,9 \\
\hline 7 & 3,1 & 0,86 & 206 & 4,84 & 0,135 & 38,2 \\
\hline 8 & 2,4 & 0,87 & 210 & 4,93 & 0,13 & 38,5 \\
\hline
\end{tabular}

Their synthesis, combustion and decomposition was established by balances of weight and heat.

Table 16: Balance of Weight and Heat for Synthesis, Combustion and Decomposition of PIR (EW= 324g/mole) and Isocyanate Reaction Heat $\mathrm{H}=50 \mathrm{~kJ} / \mathrm{mole}$

Synthesis:

Polyol $\mathrm{h}=-0,154 \mathrm{~kJ} / \mathrm{g}$

$0,34\left(\mathrm{C}_{3} \mathrm{H}_{6} \mathrm{O}\right) 2,55+\mathrm{C}_{8} \mathrm{H}_{6} \mathrm{NO}=\mathrm{C}_{15,65} \mathrm{H}_{21,3} \mathrm{NO}_{3,55} \quad 0,34 *-0,154=-0,052 \mathrm{~kJ} / \mathrm{g}$

MW $148+132=280$

H $2,55^{*}-286-91-50=870,3$

Glycerol $\mathrm{h}=-0,154 \mathrm{~kJ} / \mathrm{g}$

$0,068 * 1 / 3 *\left(\mathrm{C}_{3} \mathrm{H}_{8} \mathrm{O}_{3}\right)+\mathrm{C}_{8} \mathrm{H}_{6} \mathrm{NO}=\mathrm{C}_{9} \mathrm{H}_{8,7} \mathrm{NO}_{2} \quad 0,0154 *-0,154=-0.002 \mathrm{~kJ} / \mathrm{g}$

MW 30,7 +132=162

$\mathrm{H}-298,5-91-50=-439,5$

Ricinus $\quad \mathrm{h}=-0,154 \mathrm{~kJ} / \mathrm{g}$

$0,015 * \mathrm{C}_{18} \mathrm{H}_{34} \mathrm{O}_{3}+\mathrm{C}_{8} \mathrm{H}_{6} \mathrm{NO}=\mathrm{C}_{26} \mathrm{H}_{40} \mathrm{NO}_{4} \quad 0,015 *-0,154=-0,002 \mathrm{~kJ} / \mathrm{g}$

MW $298+132=430$

$\mathrm{H}-10875-91-50=-11016$

Isocyanate $\mathrm{h}=-0,154 \mathrm{~kJ} / \mathrm{g}$

$(2,027-0,34-0,068) * \mathrm{C}_{8} \mathrm{H}_{6} \mathrm{NO}=\mathrm{C}_{8} \mathrm{H}_{6} \mathrm{NO}$ pol $\quad 1,619 *-0,154=-0,249 \mathrm{~kJ} / \mathrm{g}$

MW $132=132$

$\mathrm{H}-91-50=-141$

$$
\mathrm{h}=-0,307 \mathrm{~kJ} / \mathrm{g}
$$

Sum: $-0,305 \mathrm{~kJ} / \mathrm{g}$

$0,867 \mathrm{C}_{3} \mathrm{H}_{6} \mathrm{O}+0,068 * 1 / 3 * \mathrm{C}_{3} \mathrm{H}_{8} \mathrm{O}_{3}+0,015 \mathrm{C}_{18} \mathrm{H}_{34} \mathrm{O}_{3}+2,027 \mathrm{C}_{8} \mathrm{H}_{6} \mathrm{NO}=\mathrm{C}_{19} \mathrm{H}_{20} \mathrm{~N}_{2} \mathrm{O}_{3}$

MW 50,3 +2,1+4,5+266,8=323,7 (324)

H $0,867 *-286+0,023 *-298,5+0,015 *-10875+2,027 *-91=-602,5-98,8=-701,3$

H -248,0 -6,9- 163,1 -184,5 - 184,5 = -787- 99,5 = -886,5

Combustion $\mathrm{h}=-30,21 \mathrm{~kJ} / \mathrm{g}$

$\mathrm{C}_{19} \mathrm{H}_{20} \mathrm{~N}_{2} \mathrm{O}_{3}+22,5 \mathrm{O}_{2}=19 \mathrm{CO}_{2}+10 \mathrm{H}_{2} \mathrm{O}+\mathrm{N}_{2}$

MW $324+720=836+180+28$

H $-549-9787,5=-7476,5-2860$ 
Decomposition

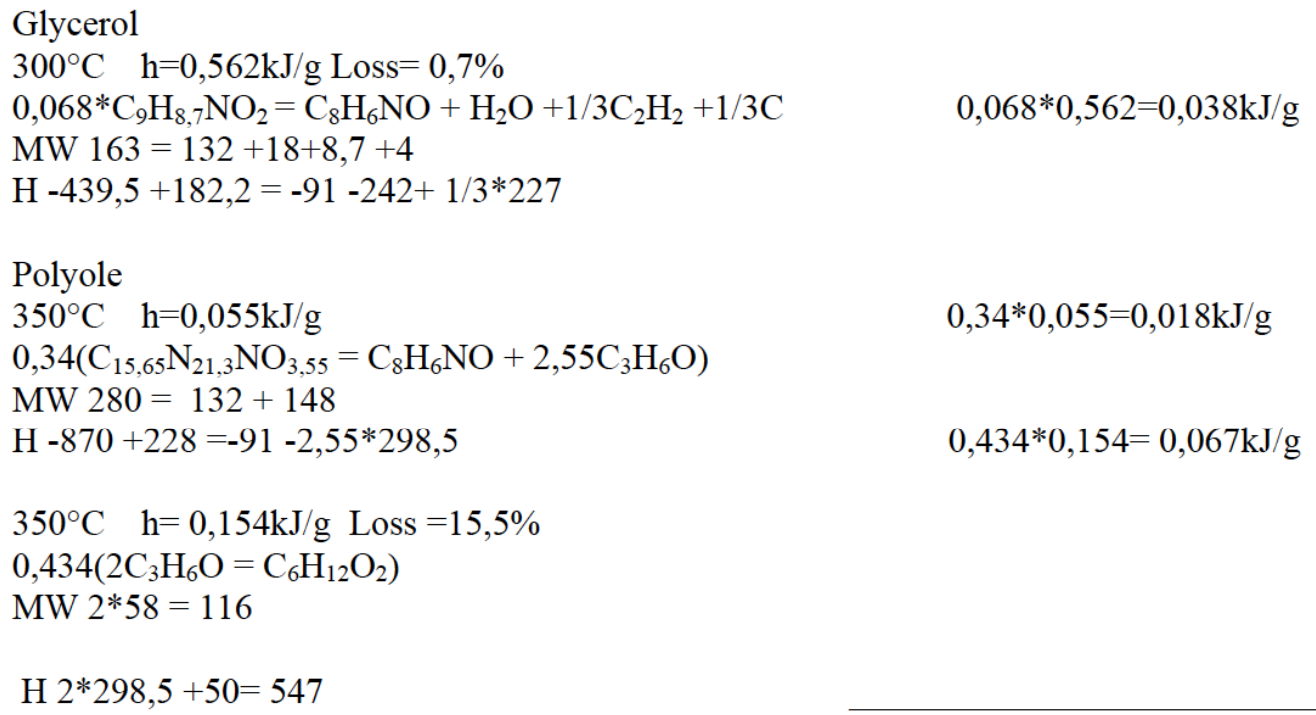

peak $1 \mathrm{R}=83,8 \% \mathrm{~h}=0,123 \mathrm{~kJ} / \mathrm{g} 350^{\circ} \mathrm{C}$

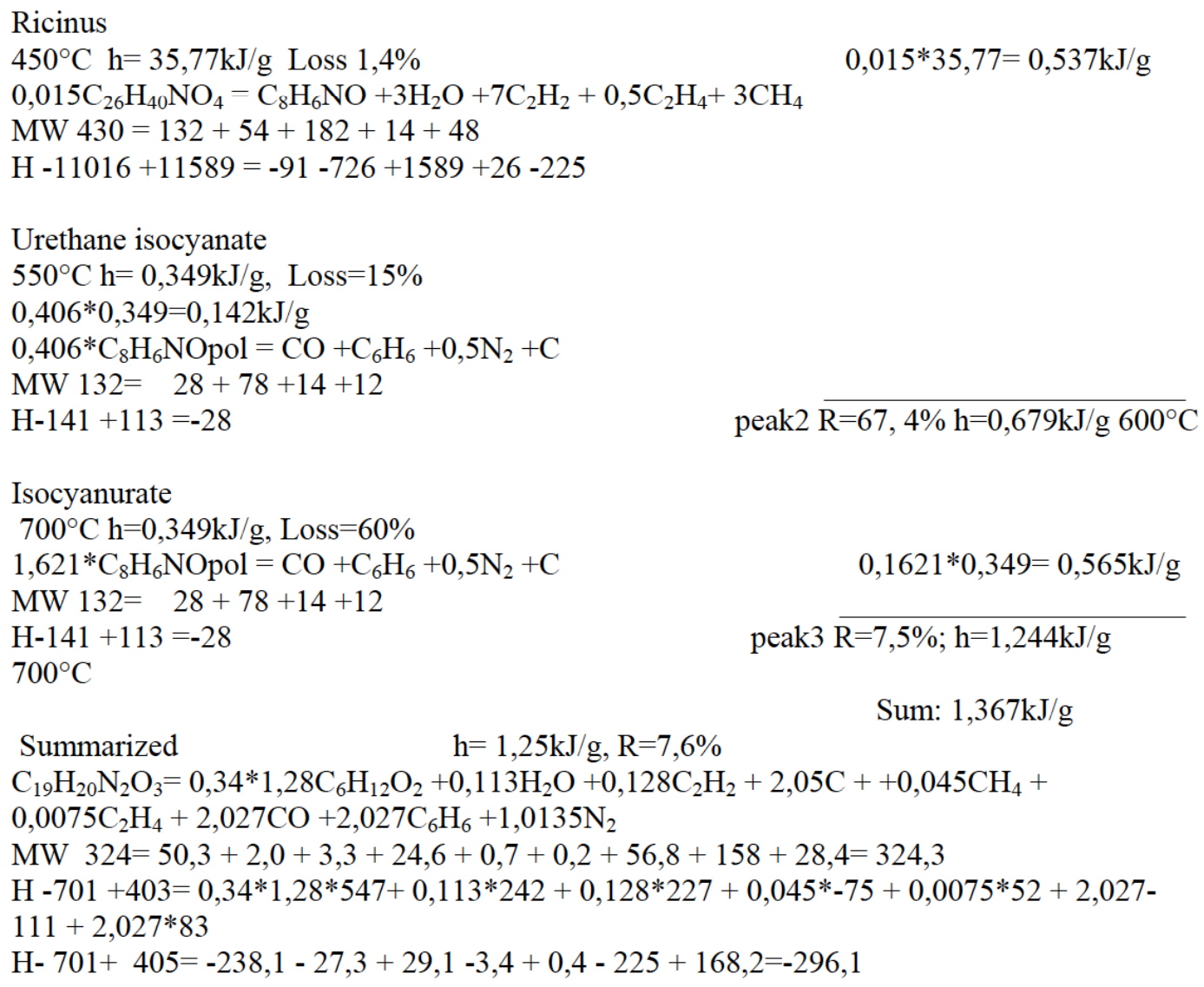

\section{REFERENCES}

[1]
Oertel G. "Polyurethane Handbook" Hanser Verlag, Munich 1985.
[3] Leppkes R. "Polyurethane Werkstoff mit vielen Gesichtern "Verlag Moderne Industrie 2003. 
[4] Allport DC, Gilbert DS, Outterside SM, Ed. "MDI and TDI safety, health and environment, a Source book and practical guide", John Eiley \& Sons Ltd 2003.

[5] Uhlig K. Polyurethan Taschenbuch 3. Aufl. Hanser Verlag, München 2006.

[6] Hübner K. "75 Jahre Polyurethane" Chemie in unserer Zeit Bd. 46 No. 22012.

[7] Avar G. "Polyurethane" Kunststoffe No.10 2006; 206-211.

[8] Lechner P. Untersuchung zum Mikrowellen unterstützten Aushärten von vernetzten Harzsystemen auf Polyurethanund Kohlenwasserstoffbasis. Dissertation der Technischen Universität Darmstadt (30.04.2012).

[9] Klempner D, Frisch KC. "Handbook of Polymer Foams and Foam Technology", Oxford University Press, New York, N.Y. 1991.

[10] Becker, Braun Kunststoff Handbuch 10 Duroplaste. Carl Hanser Verlag, München 1988; p. 47.

[11] Ashida K. "Polyurethane and Related Foams: Chemistry and Technology", Boca Raton FL: CRC/Taylor \& Francis 2007.

[12] Klempner D, Sendijarevic V. "Polymeric foams and foam Technology $2^{\text {nd }}$ ed. Hanser Verlag, Munich 2004.

[13] Lee ST, Park CB, Ramesh NS. "Polymer Foams", Taylor\& Francis (2007)

[14] Consoli S. Software to Manage a Continuous Production of Flexible Polyurethane Foams by Slabstock Technology. J Cell Plastics 1997; 33: 102.

[15] Dörner KH, Meiners HJ, Ludwig HJ PUR Teile kostengünstig fertigen. Stand der Polyurethan RRIM-Technologie. Kunststoffe 2001; 91: 4

[16] Ehbing H, Zien H, Rathaus R, Frei J. Bayer Intellectual Property $\mathrm{GmbH}$ Process and Installation for the production of foam in a continuous foaming process. US 8389590 B2 2004

[17] Bayer Material Science Verfahren und Anlage zur optimierten Herstellung von Schaumstoff in einer kontinuierlichen Blockschaumanlage. DE 102005003341 A1 2006.

[18] Horacek H. Computerunterstütze, kontinuierliche Herstellung von Polyurethan- Blockschaumstoffen. AT 401115 B 1990.
[19] Naumann J. Utech Asia 99, Fabrication of special Machines for PUR block processing.

[20] Dick CM, Denecker C, Liggat JJ, Mohammed MH, Snape CE. Seeley G, Lindsay Ch, Eling B, Chaffaujou P. Solid state $13 \mathrm{C}$ in situ $1 \mathrm{HNMR}$ study on the effect of melamine in the thermal degradation of a flexible polyurethane foam. Polym Int 2000; 49: 1177-1182.

https://doi.org/10.1002/1097-0126(200010)49:10<1177::AIDPI437>3.0.CO;2-5

[21] Herbiet R. Martial LEO-neue Aluminiumhydroxide mit verbesserten Eigenschaften. GAK 12/2008 Jg61 794-800.

[22] Duquesne S, Le Bras M, Bourbigot S, Delobel R, Camino G, Eling B, Lindsay Ch, Roels T, Vezin M. Mechanism of Fire Retardancy of Polyurethanes using Ammonium polyphosphate. Pol Sci 2001; 32: 3262-3274. https://doi.org/10.1002/app.2185

[23] Modesti M, Lorenzetti A, Simioni F, Checchin M. Influence of different flame retardants on fire behaviour of modified PIR PUR polymers. Polymer Degradation and Stability 2001; 74: 475-479. https://doi.org/10.1016/S0141-3910(01)00171-9

[24] Modesti M, Lorenzetti A. Improvement on fire behaviour of water blown PIR-PUR foams use of an halogen free flame retardant. European Polymer J 2003; 39(2): 263-268. https://doi.org/10.1016/S0014-3057(02)00198-2

[25] Naruse A, Nanno H, Inohara H, Fukami T. Development of All Water-Blown Polyisocyanurate Foam System for Metal faced Continuous Sandwich Panels. J Cell Plast 2002; 38(5): 385-401. https://doi.org/10.1177/0021955X02038005144

[26] Troitsch J. International Plastics, Flammability Handbook $2^{\text {nd }}$ ed. Hanser Publishing, Munich 1990.

[27] Nagy J, Pusztai E, Wagner Ö. Theoretical Study of the Reaction Mechanism of substituted isocyanates and alcohols. Eur Chem Bull 2013; 2(12): 985-992.

[28] Roberts J, Caserio MC. Basic Principles of Organic Chemistry, W.A. Benjamin Inc. New York 1965; 77.

[29] Physical properties of Polymers, Handbook, Mark JE, Ed. AIP Press, New York 1996. 